\title{
Vzestup a úpadek poděbradského a nymburského rybníkářství pohledem historické hydrologie
}

\section{LIBOR ELLEDER, JOLANA ŠíROVÁ, VÁCLAV DAVID, LADISLAV KAŠPÁREK, GÜNTHER KLETETSCHKA, ZVONIMÍR DRAGOUN}

Klíčová slova: značky malých vod - 1790 - historická hydrologie - rušení rybníků - Blato - Poděbradsko

"Okolnost, že z bývalého rybničního hospodářství ve středním Polabí zbyly do našich dob jen nepatrné trosky, způsobila, že velká většina prací o českém rybnikářství a rybnících, a to i prací historických, se o něm téméř nezmiňuje."

RNDr. Josef Veverka, autor publikací o rybníkárství na Poděbradsku a Nymbursku v roce 1949 před svým dlouholetým vězněním.

\section{SOUHRN}

Tématem článku je zánik rybníků anebo celých rybničních systémů v oblasti Poděbrad a Nymburka, a to zejména v obdobích sucha. Tato souvislost není zcela zjevná, když uvážíme význam rybníků v dřivějších dobách jako zásobu energie i vody. Na několika ukázkách poukazujeme na užitek, který mohl rybník poskytnout. Abychom ozřejmili tyto souvislosti, užili jsme nejstarší řady vodních stavů a také záznamy minimálních vodních stavů na hladových kamenech. Největší rybník na území dnešní České republiky, Blato, na který jsme se především zaměřili, zanikl v době katastrofálního sucha roku 1790. Může být zánik podobných rybníků vysvětlen také suchem?

\section{ÚVOD}

Období extrémních povodní 1997-2013 zdá se pominulo. Bohužel, v letech 2014-2019 byly povodně vystřídány periodou extrémního sucha. Již dnes je zřejmé, že současný nepříznivý průběh počasí má vážnější a dlouhodobější dopady než předchozí povodně. Aktuální stav má snad jedinou výhodu z hlediska odborného poznání, totiž možnost hlouběji porozumět dřivějším epizodám sucha, dokonce i těm ve vzdálenější minulosti několika staletí. Máme dobrou príležitost mnohé zaznamenat, pochopit a najít paralely v minulosti.

Obecně se soudí, že ubývání rybníků odstartovala třicetiletá válka. Rozhodující byly změny $v$ zemědělství a početní nárůst obyvatelstva zejména v 18. století [1-3]. Jinými slovy, viníkem zániku většiny rybníků byl hlad po orné půdě, po pưdě rybničních pánví, které slibovaly značné výdělky. Tak jak se prosazovaly v 18. století víc a víc osvícenské názory a z nich odvozené hospodár̆ské teorie, přestávalo mít rybniční hospodářství pověst výnosného podnikání. Novější pohledy ale upozorňují i na ekonomické aspekty, které měly pưvod již $\checkmark$ druhé polovině 16. století [4].

Pokud přihlédneme k obdobím, kdy k rušení rybníků na celém našem území docházelo, je dalším možným faktorem počasí, resp. důsledky několika velmi teplých a suchých period (1761-1766) a (1781-1811). Význam některých těchto období podtrhuje i fakt, že jako minima vodních stavů byly vyznačeny některé

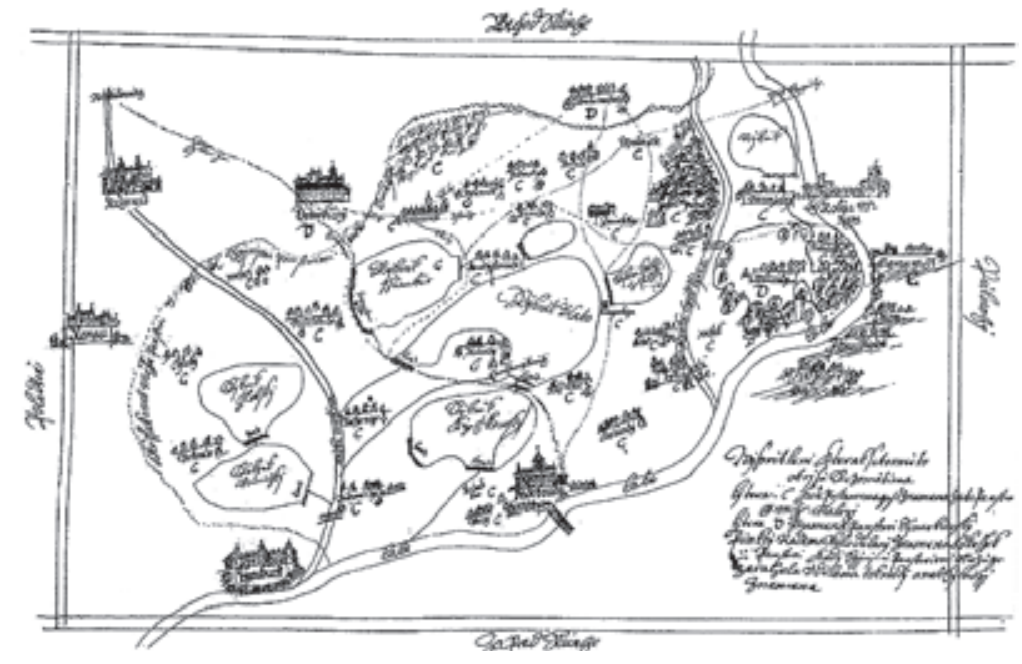

Obr. 1. Schematický plán největších rybníků Poděbradska a Nymburska z roku 1655 [20] (Fiala, Dlouhý, 1897), zleva rybník Chlebský, Bobnický, Šumbor, Blato, Křečkovský, Úmyslovický a Okřínek (?); nejsou vyznačeny př́tokové kanály, jsou ale vyznačeny hráze se stavidly regulující odtok do Mrliny a Labe; nepopsaný rybník u Kolína (v mapě nahoře vpravo) je pravděpodobně rybník Bačov

Fig. 1. The map of the largest fishponds in Poděbrady and Nymburk county in year 1655 [20] (Fiala, Dlouhý, 1897), from the left: Chlebský, Bobnický, Šumbor, Blato, Křečkovský, Úmyslovický and Okř́nek (?) fishponds; the inflow canals are not marked on this map, the fishpond dams and water gates are marked; the unnamed fishpond on the map is probably a Bačov fishpond near Kolín town

roky těchto období (např. 1761, 1782, 1790, 1800 a 1811) na hladových kamenech $\checkmark$ Labi. Ne všechny doklady tohoto druhu se ale zachovaly, ne všechny známe. Toto období bylo bohaté i na další extrémy. Jen zdánlivě paradoxně jsou to i tuhé zimy a jejich důsledky, jako tvorba nezvykle velkých sněhových zásob, neobvykle silný zámrz na řekách i na rybnících, a také pověstné povodně $v$ letech 1784, 1785 a 1799.

Námět tohoto článku se týká sucha jako možného "katalyzátoru“ vzniku a zániku rybničních soustav. Zaměřili jsme se na zrušené rybniční soustavy na Poděbradsku a Nymbursku, které patřily k největším rybochovným oblastem a kde se nalézaly naše největší rybníky, mezi nimi i možná vůbec náš největší rybník Blato. Položili jsme si ale i otázku, co bylo Blato, než se stalo rybníkem, jaký režim tu mohl panovat před zbudováním Sánského kanálu ve středověku anebo ještě dále, ve vzdálenější minulosti, snad hlouběji do holocénu a ještě před ním. 


\section{METODIKA, DATA, DALŠÍ ZDROJE A ZÁJMOVÁ OBLAST}

Kromě dobových hospodářských zdrojů najdeme jedny z nejstarších informací o nymburských a poděbradských rybnících až u historika B. Balbína (1621-1688) [5]. Z literatury 18. a 19. století jsme převzali př́klady dokumentující typické dopady sucha v oblasti zemědělství, provozu mlýnů a využití rybníků z práce V. Krolmuse (1790-1861) [6]. Dobové popisy a komentáře z období let 1770 až 1816 k dějưm na Poděbradsku pocházejí od milčického rychtáře a kronikáře F. J. Vaváka (1741-1816) [7-13]. Kupodivu minimum zmínek k tématu Ize najít v historii Nymburka od pamětníka rušení rybníků, lékaře a starosty Nymburka J. Merkla (1761-1833) [14], s nímž si F. J. Vavák dopisoval. Informace o melioračních zásazích (1883-1892) v bývalé rybniční oblasti pocházejí od někdejšího správce poděbradského panství a iniciátora regulace Mrliny L. Doležala [15]. Pro nás byly zatím nedostupné rukopisné práce $\mathrm{k}$ rybníkářství od poděbradského lékárníka, sběratele a amatérského archeologa J. Hellicha (1850-1931) [16, 17], zakladatele muzea v Poděbradech.

Pozornost věnovaná rybníkům na Poděbradsku je při porovnání s třeboňskou soustavou a dokonce i se soustavou hradeckou mnohem menší. Je to patrné téměř ze všech prací, které se rybníkářstvím a jeho historií zabývaly, včetně príležitostných pamětních spisů věnovaných historii vodního hospodářství. Zcela anebo skoro bez povšimnutí prešly nymburskou a poděbradskou rybníkářskou tradici pamětní spisy věnované vodnímu hospodářství v Čechách, jako práce prof. K. Wiesenfelda (1802-1870) z roku 1845 [18] a rady H. Franze z roku 1891 [19]. Až práce inženýrů vodohospodářu J. Dlouhého a F. Fialy z roku 1897 [20] krátce popisuje poděbradskou soustavu. Přitom autoři publikovali i unikátní mapu rybníků na Mrlině a Sánském kanále z roku 1655, kterou zde níže uvádíme.

Nejdostupnějším zdrojem k tématu jsou články RNDr. J. Veverky (1903-1971) shrnující jeho badatelskou práci o rybničních soustavách na Poděbradsku a Nymbursku [21-24]. Veverka vycházel z rybničních register, urbářü, Hellichových rukopisů a snad i mapové dokumentace z 18. století. Jako nymburský rodák mohl své práce teoreticky konzultovat s jiným významným nymburským rodákem, o generaci starším významným českým vodohospodářem a specialistou na historii Nymburka E. Zimmlerem (1863-1950). Práce J. Veverky (též novináře, politika a sociálně-demokratického poslance) na toto téma byly bohužel přerušeny jeho vězněním v období 1949-1965. V současnosti se polabské rybníky a Sánský kanál staly tématem dvou studentských prací [25, 26].

Naším cílem bylo konfrontovat vývoj rybniční sítě a jeho úpadek s dokumentárními i měřenými daty dotýkajícími se sucha a jiných extrémů počasí. Využili jsme k tomu nových dat charakterizujících minima vodních stavů Labe od roku 1516 do současnosti. Jde o protějšek povodňových značek, výšky s letopočty jsou vyznačeny na asi 30-40 dochovaných hladových kamenech v pískovcovém kaňonu Labe. Pro podpoření identifikace hydrologického sucha jsme využili i nejstarší hydrologické řady. Šlo o řadu denních vodních stavů Labe v Magdeburku z let 1728-1880, jejíž dobový opis asi z roku 1875 je uložen v ČHMú Praha. Dále šlo o řady vodních stavů a průtoků Labe v Děčíně s počátkem k roku 1851.

Velmi přibližný tvar rybníku Blato je ž̌ejmý z mapy J. G. Vogta z roku 1712 a Müllerovy mapy z roku 1720. Veverka [21] se zmiňuje o mapách komorních panství Pardubice, Chlumec, Poděbrady, Kolín, Lysá, Přerov, Benátky a Brandýs. Tyto mapy označil za "neuchované", snad ztracené či nezvěstné. Jde o mapy z konce 16. století zemského měřiče Matouše Ornyse z Lindperka (1526-1600) a jeho nástupce Šimona Podolského z Podolí (1561-1617). Zatím nejstarší mapa poděbradských a nymburských rybníků, kterou máme k dispozici, pochází až z roku 1655 (obr. 1).

Přesnější podobu poskytuje první vojenské mapování z let 1764-1783 a mapa rybníka Blata od geometra Janovského z roku 1795 (Hellichova sbírka, dnes Muzeum Poděbrady). Rekonstrukce rybníků a kanálů je provedena v GIS na základě současné topografie, dále mapy prvního vojenského mapování (existující rybník), druhého vojenského mapování z let 1842-1852 (existovala již jen

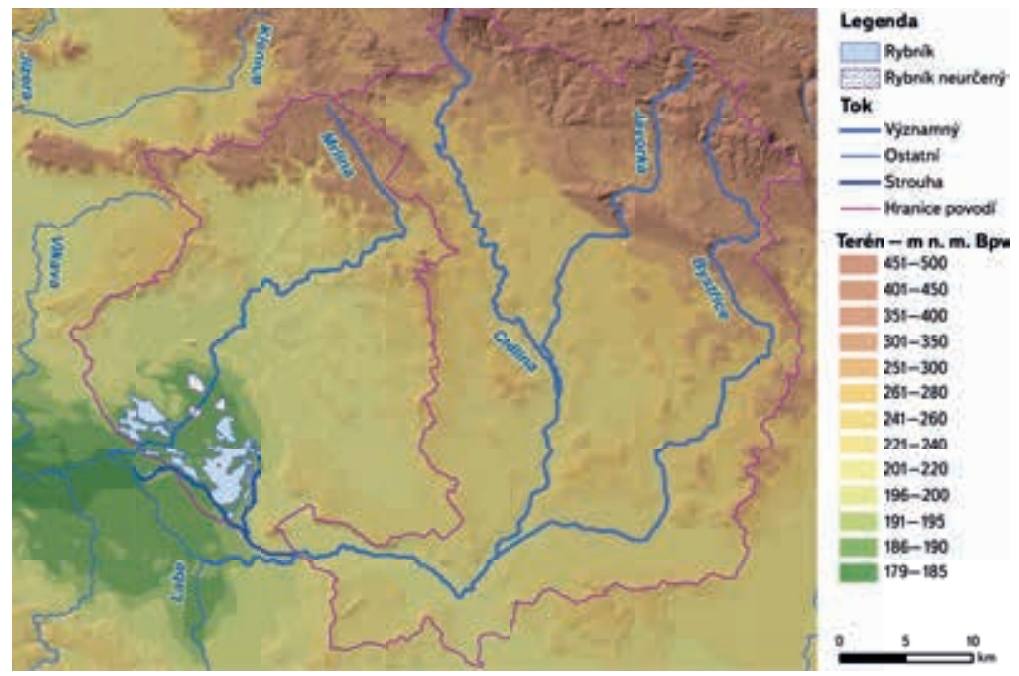

Obr 2. Reliéf oblasti výskytů rybníků v povodí Mrliny a Cidliny (zdůrazněn tok i povodí); topografie je podrobnější ve výškách 179-195 m n. m., kde se nacházejí největší rybníky a zaústění Mrliny

Fig. 2. The topography of the area of Mrlina and Cidlina rivers basins (the water stream and the border of the basin are highlighted); the detailed topography is for altitudes 179-195 $\mathrm{m}$ a. s. I., where is the occurrence of largest fishponds along with the Mrlina River estuary

velká louka "Blatowiese“) a rozsahu mokrých luk ve stabilním katastru (1826-1843). Rekonstrukci obvodu rybníků jsme konfrontovali s nákresy a popisy J. Veverky [22-24, 27]. Rekonstrukci Blata najdeme i v historickém atlase Česka [28].

Oblast nymburského rybničního systému se nacházela na pravém břehu Mrliny. Povodí Mrliny k profilu Vestec má plochu 459 km² s průměrným průtokem 1,41 $\mathrm{m}^{3} \cdot \mathrm{s}^{-1}$. Rybníky byly napájeny většinou systémem kanálů (Vestecký kanál), který se odpojoval z Mrliny v Křinci a byl podpořen pravostrannými prítoky zejména Křineckou Blatnicí. Mrlina na svém horním toku pramení v oblasti Markvartické plošiny ve výšce 378 m n. m. nedaleko Sobotky pod vrchem Čakan (399 m n. m.). Horní část se jmenovala původně Trnava, či Drnava, v literatuře se uvažovalo i o hydronymu Křinice, z níž mohl být odvozen název Křinec (v původním významu asi prameny či prameniště) [29]. Název Mrlina (ve významu pomalu tekoucí) a jiné odvozeniny souvisel asi s dolním tokem pod Křincem, tedy právě v oblasti zrušené rybničné soustavy. Za pozornost stojí silně vějiřrovité uspořádání povodí dolní Mrliny mezi Netřebicemi a Budiměřicemi, které vytvářejí zprava Křinecká Blatnice, Ronovka, zbytky systému Vestecké strouhy a potok Klobuš. Zleva jde o Velenický potok, prokopané odvodňovací kanály (soustředěné do Blatnice a druhé výpusti Blata od Koutů) a napájecí Sánský kanál zaústěný již přes sto let také do Mrliny. Mưžeme konstatovat, že současný tvar rríční sítě a pravděpodobně i současná plocha povodí se v čase měnily. Jsou výsledkem přinejmenším přes 500 let trvajících poměrně radikálních lidských zásahů do vývoje povodí.

Rybníky na levém břehu Mrliny, zejména rybníky systému souvisejícího s rybníkem Blato, byly od 15. století zásobovány z povodí Cidliny prokopaným kanálem. Dnes se pro něj užívá název Sánský kanál (najdeme v druhém vojenském mapování), přitom někdy se uvádí jako původní název Lánský kanál či Lánská strouha (najdeme v prvním vojenském mapování), ale v době vzniku to byla asi jen "Struha“ či "Strouha“. Cidlina má oproti Mrlině k profilu Sány dvojnásobnou plochu povodí $1151 \mathrm{~km}^{2}(o b r .2)$ a průměrný průtok $5,2 \mathrm{~m}^{3} . \mathrm{s}^{-1}$. Problematika rozdělování průtoku mezi kanálem a dolní Cidlinou v období provozu celého rybničního systému (cca 1470-1795) není jasná, dnes je to přibližně systém jedna ku jedné. Část průtoku byla odváděna do povodí Mrliny odpadními rybničními kanály, průtok Sánského kanálu byl nad Nymburkem odváděn do Labe. 
Zájmová oblast je tvořená křídovým podložím (opuky), na kterých se místy vytvářely sprašové návěje v době ledové, na nich pak se vyvíjely nynější půdní systémy (černozem, hnědozem).

V souvislosti s otázkami, které se dotýkají staršího vývoje rybniční pánve, jsme se rozhodli pro několik sond ve východní části Blata. Pro porovnání jsme odebrali vzorky $\vee$ jeho nejhlubši části, $v$ oblasti někdejšího ostrova Čejky. Datování problematizuje fakt, že oblast je obhospodařována a více než sto let je zde tedy prováděna i hluboká orba. Lokality s původní stratifikací vrstev jsou téměř nedostupné. Chtěli jsme se proto alespoň přesvědčit o hloubce rybničních sedimentů. Tyto sondy tak ukazují především na mocnost orniční vrstvy a charakter podkladu. Šlo tedy i ověření možného maximálního objemu vody celého rybníka.

\section{VZNIK RYBNIČNÍCH SOUSTAV NA NYMBURSKU A PODĚBRADSKU VE 14. AŽ 15. STOLETÍ}

J. Veverka dává celé polabské rybníkářství (asi zejména na Hradecku) do souvislosti s ranou klášterní kolonizací [též 30] a benediktinským klášterem v Opatovicích (1086-1421) [21]. Rybniční hospodářství a vznik velkých rybníků na odbočujícím kanálu z Labe (předchůdce pernštejnského Opatovického kanálu) jsou doloženy alespoň již ve 14. století [27].

Z faktu, že oblast za Nymburkem patřila do roku 1291 hradištským a později sedleckým cisterciákưm, usuzuje J. Veverka [23, 24] na starší rybníkářskou tradici již ve 13. a 14. století. Připouští, že v místech na pravém břehu Mrliny mohl existovat již v 15. století Chlebský rybník a menší rybník v místech pozdějšího rybníka Bobnického. Největší rybník Blato, na levém břehu Mrliny, byl podle stejného autora [22] zřízen již ve 14. století a byl zásobován "splachovými vodami“, patrně tedy zejména z dlouhého hřbetu mezi Oškobrhem (295 m n. m.) a Vršálem (cca $210 \mathrm{~m} \mathrm{n}$. m.). Podle něj ale i dalších autorů [4] bylo podmínkou pro další rozvoj místního rybnikářství vytvoření větších pozemkových celkư v období po husitských válkách. To se roku 1437 na Poděbradsku podařilo Jiř́mu z Poděbrad a zčásti o něco později královskému městu Nymburk [21, 22]. Následně hrálo značnou roli zklidnění politické situace po střetech mezi Českým královstvím a Uhrami, ke kterému došlo až po smrti Jiř́ho roku 1470. Kromě vlastnických vztahů a politické situace, mohly hrát svou roli i prírodní podmínky, tedy i meteorologické a hydrologické extrémy.

Suché periody se podle posledních publikovaných výsledků historické klimatologie u nás [31] vyskytly v letech 1441, 1442, 1461, 1469, 1471, 1472, 1473, 1476 a 1482. Perioda s výskytem suchých let 1469-1476 vyvrcholila v letech 1471 a 1473. Můžeme to dokumentovat výmluvným popisem z Hájkovy kroniky k roku 1473 [32]: „Toho léta bylo velmi velké sucho, neb déšt za půl čtvrta měsíce [3 a 1/2 měsíce, pozn. autora] nepršel a horko velké bylo, mnozí přeschly potokové, v rybnících některých i v jezerách se voda zkazila, takže z toho byli lidem velmi nepř́ijemné smradové a tudy moru přibývalo." Tato Hájkova citace se dotýká zajímavým způsobem právě jisté slabiny mělkých polabských rybníků.

Nejdřive po roce 1445, ale spíš až po roce 1470 vznikl Sánský kanál, který u tvrze Badry odbočoval "Baderskými stavidly“ od řeky Cidliny (obr. 3). Odebíral tak podstatnou část průtoku, aby tak přivedl dostatečné množství vody do „poděbradských blat", bezodtoké oblasti, o jejímž charakteru předtím nemáme spolehlivý doklad. V literatuře najdeme jak označení „blata“ či "jezero", tak "nebeský rybník", spolehlivý dobový literární zdroj zde ale chybí. Blato se tak stalo již koncem 15. století, díky pánům z Kunštátu, zdaleka největším rybníkem v Čechách. Jeho plocha totiž mohla přesahovat $10 \mathrm{~km}^{2}$. Přitom podle dostupné historické dokumentace byl u nás ve stejné době patrně největším rybníkem rybník Dvořiště s plochou asi 3,5 km². Podle pravděpodobnější verze vzniku Sánského kanálu (1470 anebo dokonce 1475) mohl být zakladatelem nového rybničního systému Blata snad Hynek z Kunštátu a na Poděbradech.
Výhodou Blata bylo, že teoreticky nepotřebovalo žádnou hráz, nehrozilo proto ani její protržení. Hrází byly patrně odděleny, asi až později, části původní sníženiny pro relativně menší rybníky (např. rybník Úmyslovický čili Rohlík a rybník Vyhlíd jižně od něj, obr. 3), takže plocha Blata se asi poněkud redukovala na 9,7 km². Voda ze Sánského kanálu se napouštěla stavidly v obci Pátek. Bylo to před profilem dnešního mlýna v Pátku, který ale tehdy ještě neexistoval. Nejasné jsou okolnosti zbudování Nových mlýnů u obce Odřepsy na Sánském kanále (15. století) o němž se traduje, že byl náhradou za mlýn v Libici na Cidlině, kterému se za nové situace nedostávalo vody. Sánský kanál ale nebyl jediným oslabením průtoku Cidliny. Po roce 1470 byl zbudován ještě „Bačovský kanál“, který dotoval další rozlehlý rybník Bačov (odhad plochy alespoň 2 km²) na tehdejším kolínském panství. Bylo to logické, Kolín totiž patřil od roku 1471 Viktorinovi a později Hynkovi z Kunštátu. Bačov i s odtokovým kanálem směrem k Velkému Oseku je zobrazen na schematickém plánu z roku 1655 (obr. 1) a popsán jen jako „Rybník”. Jako značně zarostlý a mělký rybník je ještě vyznačen na mapě prvního vojenského mapování. Pozůstatkem tohoto rybničního systému je dodnes alespoň zčásti tzv. „Bačovka“ ústící v NPR Libický luh do Labe.

\section{VRCHOLNÉ OBDOBÍ 1495-1565}

Začátkem 16. století vznikaly další velké rybniční projekty na Hradecku a Chlumecku, např. slavný rybník Čeperka anebo Žehuňský rybník na Cidlině, položený ještě nad Baderskými stavidly. Poděbradské panství se stalo roku 1495 komorním, tedy majetkem krále. Další kanály, kterým se Blato odvodňovalo směrem do rybníků Hrádkovského a Budiměřického (obr. 3) byly povoleny Vladislavem II. podle J. Veverky [21] roku 1497. J. Merkl [14] uvádí ale rok 1491: „ve štvrtek po svatým Prokopu [7. 7.]... aby z císařského [!] poděbradského rybníka Blata podzimní a jarní voda struhou, kterou město nákladem svým udělati se uvolilo, do rybníkův nymburských spuštěna byla."

V roce 1501 postihla Bavorsko, Rakousko, Čechy a Slezsko katastrofální povodeň. Zasažena byla rozsáhlá území povodí Odry, Labe i Dunaje. Je docela pravděpodobné i rozvodnění Cidliny a Mrliny (doklad zatím ale chybí). Z hlediska opačného extrému, tedy sucha bylo podle soudobých prací historické klimatologie věnovaných suchu [31,33] nejvíce kritických epizod v letech 1511-1520 a znovu v dekádě 1531-1540. Presto uprostřed suššího období, v roce 1515 došlo k několika povodním, z nichž srpnový případ se mohl týkat podle "Starých letopisů českých“ i povodí Cidliny [34]: „mnozí rybníkové se strhali pernštejnskému a Trčkovi, dobytek obilé i lidi brala, v Kolíně na mostě ji dosahovali." Lokalizace „Trčkovi" odkazuje snad na "trčkovské panství. K němu náležel hrad Veliš u Jičína, později v 17. století rozebraný. To pak umožňuje uvažovat o rybnících v povodí horní Mrliny anebo o původně velké soustavě „Ostruženských rybníkư" s dodnes nejasnou dobou vzniku. Zda se mohl „strhat" i někdejší obrovský rybník Podhradský čili Porák, který byl ještě koncem 18. století jejich součástí, nevíme.

Velmi nízké odtoky z české části povodí Labe potvrzují nově zjištěné značky minimálních odtoků v Děčíně a Dolním Žlebu. Jde o následující léta 1516, 1517 (podle farní kroniky v Dolním Žlebu, SOkA Děčín) a také rok 1536. Vyvrcholením těchto suchých let byl rok 1540, který se stal v celé střední Evropě pověstný jako nejsušší v 16. století [31].

Kolem roku 1509 byl zřizen na pravém břehu Mrliny vedle Vestce (na obr. 3 vyznačen schematicky) veliký Jílecký rybník [23, 24]. Téhož roku, podle smlouvy mezi městem Nymburkem a Jiřím Křineckým, majitelem sousedního Ronovského panství (zámek Nový Ronov byl nedaleko Křince v obci Oskořínek, po roce 1930 byl stržen), vznikly strouhy pro zásobení nových rybníků. Šlo snad o tzv. „Vestecký kanál“ z Mrliny, který odbočoval u Křince, aby zásoboval postupně se rozrůstající systém rybníků na pravém břehu Mrliny (jen schematicky obr. 3). Níže po toku vykupovalo město Nymburk po roce 1500 pozemky, patrně pro zamýšlený či rozšiřený rybník Bobnický (někteří autoři uvádějí 


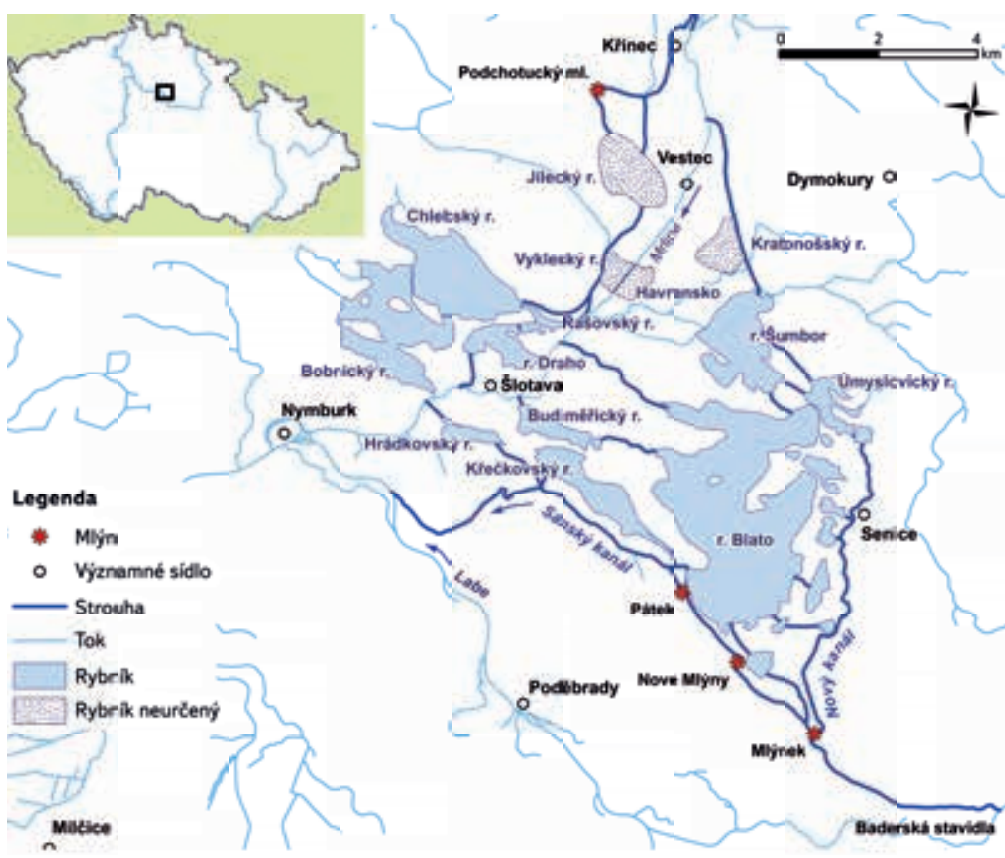

Obr. 3. Rybníky poděbradské a nymburské rybniční soustavy na základě rekonstrukce: trasa Sánského kanálu (strouhy) a Nové kanálu (strouhy) v její původní podobě; trasa Vesteckého kanálu (strouhy) od Křince je provedená zjednodušeně stejně jako zatím obtížně určitelný tvar a poloha dřive zaniklých (1650-1740) velkých neurčených rybníků (Jílecký, Vyklecký, Havranský a Kratonošský), vlevo dole obec Milčice, bydliště kronikáře F. J. Vaváka, komentátora dění na Poděbradsku 1770-1816

Fig. 3. The fishpond system of Podébrady and Nymburk based on our reconstruction; the position of the Sánský kanál and Nový kanál (or Nová strouha) canal are shown in its original state; the direction of the Vestecká strouha canal from Křinec village is approximately outlined as well as the very approximate shape of earlier (1650-1740) discontinued fishponds (Jílecký, Vyklecký, Havranský a Kratonošský fishponds). The village Milčice (the residence place of notable chronicles writer and Poděrady life commentator F. J. Vavák in 1770-1816), is in the lower left corner of the Figure

Křechovský [22] anebo dokonce Kašparovský [20]) o výměře asi 2,7-3km². Již $\checkmark$ roce 1514 bylo podle register rybníků Chlebského a Bobnického prodáno 132 džberů kaprů (asi 8000 kusů). V roce 1531 se rada města Nymburka a purkmistr s odvoláním na válečné výdaje (turecké tažení roku 1529 a vojenskou reakci roku 1530) omlouvali královské komoře, že nevyčistili svůj díl řeky Mrliny (přibližně pod Vestcem). Tak se podstatně zhoršoval odtok odpadními kanály mezi Rašovicemi a Šlotavou ze systému nymburských ale i poděbradských rybníků kolem Blata [22].

Podle J. Veverky [22] byl odbočkou z Mrliny zásoben i nadýmací Podchotuční (či Podchotucký) rybník a stejnojmenný mlýn východně od Křince a pod ním zmíněný Jílecký rybník. Systém struh se větvil a zásoboval Havranský rybník i Vyklecký rybník a níže vlevo rybníky Rašovický, Draho a víc k západu rybníky Chlebský a Bobnický. Přiznáváme, že v tom jaká byla přesná trasa struh, tvar a poloha horních rybníků není zatím zcela jasno (schematicky obr. 3). Můžeme poznamenat, že ve stejné době dochází k výstavbě velkých rybnikářských staveb také jinde, v letech 1508-1520 vznikla např. věhlasná „Zlatá stoka“ Štěpánka Netolického k zásobní třeboňské rybniční sítě.

Podle některých indicií dosáhly nymburské rybníky maximální rozlohy až někdy po roce 1542 [22]. Tehdy, dva roky po katastrofálním suchu se prováděly rozsáhlejší opravy jejich hrází. Roku 1547 prrišel Nymburk při konfiskaci o tři velké rybníky Šumbor, Hrádkovský a Budimeřický, a to ve prospěch Poděbrad. $\checkmark$ roce 1549 dosáhla popularita poděbradských ryb vysokého stupně, svědči o tom fakt, že tzv. "džber poděbradský" se stal oficiální směnnou jednotkou při prodeji ryb [35]. Podle urbáře z roku 1553 bylo do obou rybníků Chlebského a Bobnického nasazeno rekordních 1200 kop kaprů [22] a bylo zvažována [36] blíže neurčená lokalita u Budiměřic pro založení nového rybníka (snad šlo o rybník Draho?). Kryštof Prog, poděbradský hejtman, popsal 9. října 1565 špatný stav některých rybníků a nutnost jejich opravy takto [25]: „aby se při rybníce velkým u Nymburka, jenž Křečkovským slove, trouby některé jsou prohnilé a skleslé, takže kdyby se ta věc neopatřila a k nápravě nepřišla, jest se obávati znamenité škody a stržení toho rybníka" [25]. Uvádí dále, že rybníky Bobnický a Chlebský budou přiští rok vypuštěny, protože již „šestkrát za sebou nasazeny byly“. Žádá také rozsáhlejší opravy stavidel a navýšení některých hrází. Požaduje i opravu hráze Rohlíka (Úmyslovický r.), což byla zároveň hráz, kterou byl oddělen od rybníka Blato.

\section{5-1618 OBDOBÍ POVODNÍ A POČÍNAJÍCÍHO ÚPADKU?}

Posledních čtyřicet let 16. století bylo období s neobvykle vysokým počtem povodní, přesto se vyskytly i suché roky. Ty kriticky suché se vyskytly na konci období, byly to roky 1590, 1616 [31] a 1617 (viz dále). České rybniční soustavy s ohledem na klidnější politickou situaci od 70. let 15. století až po třicetiletou válku dosáhly svého "zlatého věku“. Doba a tehdejší právní systém byl příznivý vzniku územně ucelených panství. Zdá se, že taková situace byla vhodná pro vznik velkých rybničních soustav jako na panství Nymburském, Poděbradském, později na Hlubockém (za Pernštejnů), na panství Chlumeckém, Kolínském, na Hradecku a ještě později na Třeboňsku. Tehdy (pokud alespoň dnes víme) vznikly velké rybníky nad 200 ha jako např. Bačov či Bačovský, Bezdrev, Blato, Bobnický, Bohdanečský, Čeperka, Dářko, Horusický, Chlebský, Velkochlumecký, Oplatil, Rožmberk, Svět, Šumbor, Rutvas [Rot Fass = Rudý sud, pozn. autora], Rožemberk, Žehuň a další. V tabulce 1 uvádíme pro srovnání rybníky s plochou nad 2,5 km² (proto rybníky Dářko, Rutvas a Velkochlumecký s plochou „jen“ 2 km² v tabulce chybí). Někteři současní autoři [3, 4] vidí počátek snižování výnosnosti rybníků překvapivě již v druhé polovině 16. století, a to ze tří důvodů:

1. př́liš velká nabídka ryb a stagnace cen,

2. jiné možnosti podnikání (např. pivovarnictví),

3. v důsledku tzv. II. říšského mincovního řádu (rok 1551) výrazně rostou nominální peněžní náklady na cenu surovin i námezdní práce.

Z toho plyne, že možná některé rožmberské (Krčínovy) podniky, zejména rybníky Hrádeček, Svět či Rožmberk vznikly v době již méně příznivé. S ohledem na cenovou revoluci a vzrůst ceny práce, přestává být dřivější ekonomická výhodnost rybničního hospodárství proti polním hospodářství evidentní. Odkazujeme se tu na poznámku přičítanou v Dubraviově práci Vilému z Pernštejna jako věrohodné autoritě. Šlo v ní o sázku na větši šanci splacení dluhů majitelů dvou panství rozdílně založených. Touto poznámkou ilustroval historik J. Vorel výhodnost tehdejšího rybnikářství [4]: „Odvážil bych se uzavř́ít sázku s kýmkoliv z vás a dát jako zástavu základ ne nepatrný - a to bych jistě neudělal, kdybych rybníky důkladně neznal a neprozkoumal - že tento zaplatí prodejem ryb dluh mnohem rychleji, než onen senem, ječmenem a zeleninou. O tolik jsou př́ijmy z ryb větší než z ostatního hospodářství..." Postupně bylo pro rybnikáře v rybničním cyklu stále větším ekonomickým pokušením častější osévání letněných rybníků, tak jak „Pernštejnova sázka“ začínala být stále méně spolehlivým vodítkem [4].

Ve stejné době, roku 1562 povolila česká komora vybudování dílčích výpustních struh rybníka Blato. V roce 1569 při komisionální prohlídce navrhl pan „puchhalter české komory“ Domažlický z Riegersburku novou strouhu a další rybníky. Blato nemělo ve své blízkosti dostatek výtažních rybníků. 
Posudek hejtmana pardubského kraje Buriana Svitkovského ze Škudel a na Skalici a Petra Kurky o stavu rybníka Blato dokládá, že je mělký a dává „malý užitek". Doporučili proto vysazování jen na dvě horka (na dva roky), aby se zlepšil dosavadní malý výnos. V letech 1576-1578 vznikly na jihovýchodě Blata nové rybníky (možná tak trochu „bez stavebního povolení). Byly to rybníky Zasmušil, Okř́nek a Nadymač. Až v roce 1579 totiž povolila česká komora zbudování odbočující nové napájecí „strouhy" (na obr. 3, Nový kanál) a nových 10 rybníků (ale tři z nich již byly hotové). Do konce roku 1579 byla dokončena jak nová strouha (Nový kanál), tak zbývajících 7 rybníků (Nadymač na 150 kop, Okř́nek na 290 kop, Zasmušil na 600 kop, Skoukal na 300 kop, Veprík na 60 kop, Vyhlíd na 400 kop, Kaňka na 150 kop, Vyhnal na 100 kop, Zelinka na 50 kop a Rohlík na 200 kop kaprí násady.) Jistá opatrnost České komory se projevila v tom, že již nebyl realizován velkých Progův záměr, prededpokládající v roce 1579 vybudování i nového „obra“, totiž rybníku s násadou asi 1300 kop kaprů (78 000 kusů). Kde rybník mohl být, můžeme spekulovat, na mapě prvního vojenského mapování je zřetelná sníženina severně od rybníka Šumbora, na obr. 1 je patrné volné prostranství mezi Šumborem a Mrlinou. Stojí za to si uvědomit, že asi ve stejné době začal J. Krčín usilovat o stavbu Rožmberka [1].
S pomocí produkce rybničního hospodářství kryli v této době své dluhy jak Rožmberkové, tak další velmožové včetně panovníka (např. $[1,4])$. Celá zásilka ryb (165 džberů kaprů a 24 džberů štik), zaslaná poděbradským správcem Progem do Prahy v roce 1587 (?), byla zabavena na pokrytí finančních pohledávek věritele [1]. Velké sucho roku 1590 bylo porovnáváno i s rokem 1540, podle Jana Piláta Rakovnického, staroměstského konšela a později purkmistra [37], hladina Vltavy v Praze klesla hluboko pod korunu jezů: „Item sucho veliké, takže jezové všichni oschli a nad vodu čněli, půl druhý čtvrti lokte [asi $22 \mathrm{~cm}$ pod jezem, vztaženo do profilu vodočtu Staroměstské mlýny $-22 \mathrm{~cm}]$, nepamatovali sme od 50 let [odkaz k roku 1540] tak malé vody."

V letech 1599-1602 měl být zdokonalen systém náhonů na Mrlině a jejich vyčištění, což je podrobně popsáno J. Veverkou [23, 24]. Předznamenáním konce tohoto období jsou zimní povodně 1615 a následná velká sucha 1615 až 1616 [31], kdy opět řada toků vyschla. Výmluvným dokladem skutečně velkého sucha a velmi nízkého vodního stavu Labe, je jedna z nejnižších značek na Hladovém kameni v Děčíně z roku 1616.

Tabulka 1. Vybrané nejvètší rybníky nad 250 ha, jejich založení a prípadný zánik

Table 1. Selected largest ponds over 250 ha, their establishment and eventual extinction

\begin{tabular}{|c|c|c|c|c|}
\hline Rybník & Povodí & Rozloha A [km²] & Doba založení & Zánik \\
\hline Blato & Sánský k. & 9,7 & $1470 ?$ & 1790 \\
\hline Čeperka & Opatovický k. & $(8,0) ?$ & $1496^{*}$ & cса 1783 \\
\hline Rožmberk & Lužnice & $6,7(7,2) ?$ & $1584-90$ & E \\
\hline Bezdrev & Lužnice & $4,2(5,2)$ & $1490-2$ & E \\
\hline Horusický r. & Lužnice & $(4,4)$ & 1515 & E \\
\hline Dvořiště & Lužnice & $3,4(4,0)$ & $1366-7$ (1582) & E \\
\hline Svět & Lužnice & $3,6(3,3)$ & cca 1570, 1611 rozdělen & E \\
\hline Záblatský & Lužnice & $2,6(3,3)$ & 1475 & E \\
\hline Velký Tisý & Lužnice & $3,2(3,9)$ & 1505 & E \\
\hline Bobnický & Mrlina & 2,0 & $1530-40$ & 1784 \\
\hline Bohdanečský & Opatovický k. & $(3,5)$ & $1496 ?$ & Obnoven \\
\hline Oplatil & Opatovický k. & $(3,3)$ & cca $1500 ?$ & cca 1783 \\
\hline Záblatský & Lužnice & 3,1 & $1475-9$ & E \\
\hline Šumbor & Mrlina & 3,0 & pred 1547 & 1795 \\
\hline Máchovo j. & Ploučnice & 3,1 & 1366 & E \\
\hline Chlebský & Mrlina & 3,0 & $1530-40$ & 1784 \\
\hline Nesyt & Dyje & 3,0 & 16. stol & E \\
\hline Žehuň & Cidlina & 2,6 & cca 1500 & E \\
\hline Bačov & Bačovský k. & $2,5^{* *}$ & cca 1500 & $?$ \\
\hline
\end{tabular}

Poznámky:

E-rybník stále existuje

() plochy podle [20]

* Situace pưvodního rybníka Čeperka, jeho rozloha a poloha pưvodního kanálu v době před zničením Opatovického kláštera není jasná

** hrubý spodni odhad plochy rybníka 


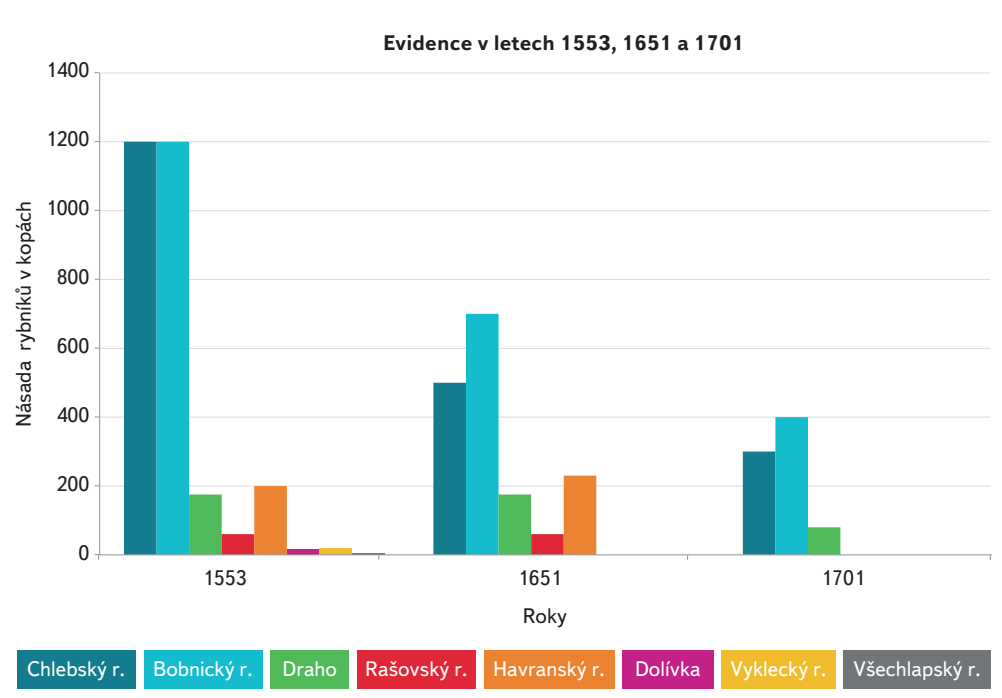

Obr. 4. Násady velkých nymburských rybníků v kopách [1 kopa = 60 kaprů] podle záznamů z let 1553, 1651 a 1701 [23, 24]

Fig. 4. The production of carps in Nymburk's fishponds; the counting is based on the records from years 1553, 1651 and 1701 and in old units "kopa" couting 60 carpes [ $1 \mathrm{kopa}=60$ ]

\section{CHLADNÉ OBDOBÍ 1620-1740}

Z hlediska klimatologie je součástí této periody období tzv. Maunderova minima (1645-1715), tedy období, které je pokládáno za nejchladnější v rámci tzv. Malé doby ledové (cca 1270-1850). Kromě četných povodní (1651, 1655, 1675, 1682, 1698 a 1712) jsou zde ale i období sucha. Ta jsou doložena asi do roku 1642 a později řidčeji jen kolem roku 1680. Jako riziko pro rybniční soustavy musíme ale zdưraznit i mimořádné zimy, a to např. tuhé zimy 1654/1655, 1694/1695, 1708/1709 a 1739/1740, tak jak některé prezentoval ve své práci o vývoji klimatu po roce 1700 např. S. Brönimann [38].

Třicetiletá válka (1618-1648) se někdy považuje, s ohledem na zanedbání údržby a prímé poškození rybníků, za hlavní příčinu úpadku rybnikářství u nás. Jako př́iklad se někdy uvádí rybník Hrádeček na Třeboňsku [1]. Podle novější práce J. Vorla o pernštejnských rybnících [4] se ale především zhroutil systém velkoobchodních smluv a dlouhodobých splátek. Tato rána "do vazu“ složitého systému obchodu s rybami, na rozdíl od snáze odstranitelných škod na rybnících a kanálech, je podle něj hlavní př́činou následného úpadku. V povodí Mrliny je ještě roku 1632 zmíněn obrovský Jílecký rybník u Křince s násadou 300 kop (18 000 kusů) kaprů, a to je asi poslední zmínka o něm [23, 24]. Velké problémy můžeme doložit již v letech 1638 na nedalekém panství Kost (povodí Klenice). Ukázku přebíráme od J. Pekaře z knihy o Kosti [39]. Hejtman Vodička informuje vrchnost o katastrofální situaci: „Pšenice někde suchem vyhořely, ovsy i ječmeny podhořelé jsou" a o nedodání pšenice do panského pivovaru. Byly užity donucovací prostředky jako žalárování přes šedesátky poddaných, a to jen proto, aby byla získána potřebná surovina k výrobě piva. Následné suché roky 1641 a 1642 byly doloženy tamtéž, tak roku 1642: „Největši škodu utrpělo panství [Kost, pozn. autora] na rybnících. Tou dobou hrozné sucho zbavilo všechny mlýny vody, a hladové partaje [špatně placení císařští vojáci, pozn. autora], aby opatřily panským mlýnům vodu, nezbytnou k semletí nakradeného obilí, spouštěly rybníky!" O stavu rybníků na Poděbradsku v roce 1642 informuje rukopis Jiřika Refigia z Kleefeldů, hejtmana panství Poděbradského, podle nějž bylo tehdy celkem 38 rybníků (9 potěrových, 14 výtažních, 15 kaprových) a jejich násada činila v úhrnu 7960 kop kaprů (500 000 kusů) [25]. Rok 1645 je uváděn jako počátek Maunderova minima, v roce 1648 končí třicetiletá válka.

V povodňovém roce 1651 „Registr urburní uvádí, že i zde „škodila na panství" voda. Mohlo jít o následek doložených lijáků v květnu [34]. Při povodni byla zaplavena luka, a to i pro zanedbání odpadních př́kopů a odvodných struh [22]

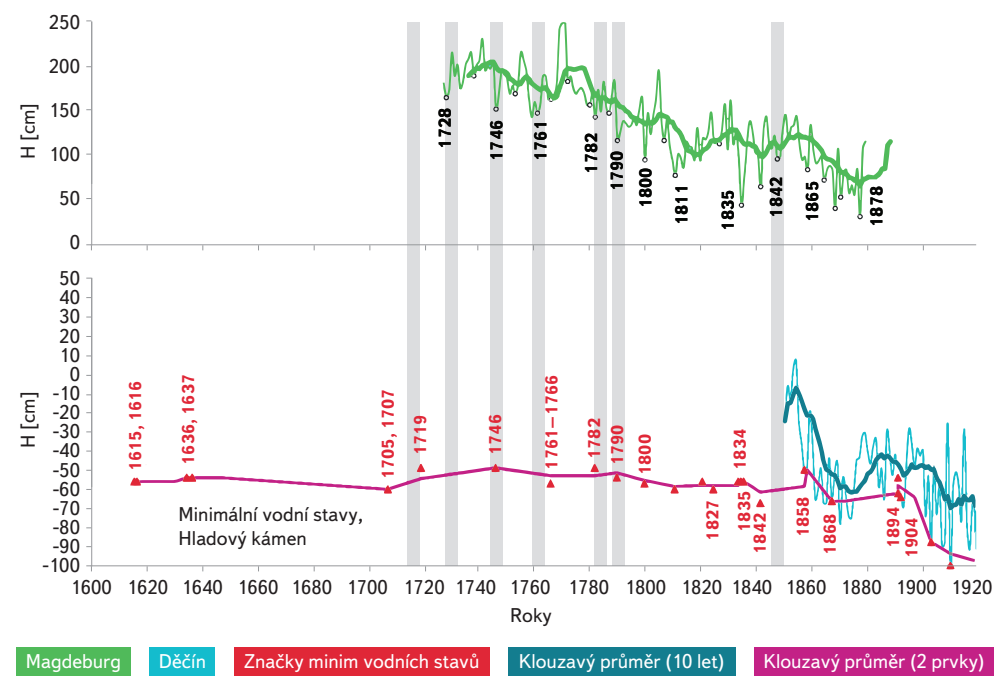

Obr. 5. Souvislost rušení rybníků v okolí Lysé n. L., Nymburka a Poděbrad (šedé pruhy 1715, 1729, 1746, 1761, 1784, 1790) s periodami nízkých vodních stavů zaznamenaných v Děčíně (červené trojúhelníky a spojující čára, značky minim, Hladový kámen; modře vodní stavy na vodočtu 1851-1920) a Magdeburku (nahoře slabá zelená čára s kolečky (roční minima vodních stavů), silná zelená čára trend ročních minim vyrovnaný klouzavě (30 let); poklesový trend souvisí se zkracováním a zařezáváním Labe v Sasku a Sasku-Anhaltsku a místními změnami v Magdeburku

Fig. 5. The relationship between discontinuing of fishponds in estates of Nymburk and Poděbrady (years in grey 1715, 1729, 1746, 1761, 1784, 1790) with periods of low flow recorded in town Děčín (red triangles and red line; in blue are water levels recorded using a Děčín gauge during the years of 1851-1920 and also Magdeburg gauge); upper diagram contains a thin green line with circles (yearly water levels minima), thick green line is the same record smoothed by 30 years mean; the decreasing trend is interpreted by shortening of Elbe River and by incision of Elbe River in Saxony

O tom, jak přestály zdejší rybníky velkou zimní povodeň 1655 [34], kterou prodělala celá střední Evropa, a která ohrožovala i tehdy málo naplněný rybník Rožmberk [1], nevíme zatím nic. Jisté ale je, že neudržovaná napájecí strouha a také řeka Mrlina zatápěly často okolní pozemky. Jak vypadala rybniční soustava v té době, ukazuje mapa z roku 1655 (obr. 1). Autor zde schematicky zakreslil Labe, Cidlinu, Mrlinu a nejdůležitější rybníky obou soustav, jsou tu hráze a odpadní kanály do Mrliny a Labe, ale nejsou vyznačeny napájecí strouhy.

$\checkmark$ roce 1658 byla postavena na Mrlině u Vestce stavidla a voda byla údajně odvedena (asi odpadní strouhou) přes rybník Šumbor na jedné a přes vestecký kanál (od Vestce se připojovala do něj strouha), na druhé straně až ke Šlotavě (obr. 3). Tak mohl být realizován (za cca 2500 zlatých) projekt spádové i směrové úpravy koryta Mrliny (viz dále) a její prohloubení. Revize a čistění Mrliny se opakovaly následně každou dekádu [23, 24].

Rybník Blato zmiňuje v kapitole spisu „Rozmanitosti z historie království českého" [5] v kapitole „O českých rybnících“ B. Balbín. Docela správně zde ukazuje, že „prvenství v rybnících mají panství třeboňské, krumlovské, budějovické, pardubické, poděbradské, chlumecké, rožd’alovické a kopidlanské". Vyzdvihuje pardubicko se čtyřmi sty rybníky s největším českým rybníkem Čeperka a Vyplatil (Oplatil). Až po popisu rybníka Rožmberk dodává: „jiný je rybník Svět u Třeboně a další jménem Blato u Poděbrad. Tyto rybníky překonávají všechny velikostí, nikoliv však př́ijemnou chutí ryb. Tu nezpůsobuje sama velikost, ale kvalita dna, jež poskytuje rybám bohatou stravu“. Balbínův názor se dotýká období asi před rokem 1676.

Úpadek rybochovu již v 17. století potvrzuje i snižování násady velkých nymburských rybníků (Bobnický, Chlebský a Draho) a zánik rybníků menších (Vyklecký, Dolívka, Havranský a Všechlapský) jako rybochovných již před rokem 1701 (obr. 4). Rušení rybníků registrujeme již před rokem 1715 či 1729, a to bez toho, že by byla zcela jasná příčina. 
Zajímavé je zdůvodnění v urbáři poděbradského panství z roku 1707 [23, 24] u dvou velkých rybníků napájených umělým kanálem od Křince: „Vyklecký a Rašovický rybník (obr. 3) se již od mnoha let nepoužívají, jsou velmi rákosem zarostlé a bahnem zapěněné, takže je spravit a vyčistit téměř nelze. Zvláště za tuhé zimy voda se v nich kazí a náramně nasmradí, takže se nesmí pouštět na dolejší rybníky." Můžeme v tom číst i možný vliv kruté zimy 1694/1695. Hluboký zámrz se opakoval jistě i v době pověstné kruté zimy roku 1708/1709. V letech 1705, 1707 a 1719 jsou zaznamenána sucha a velmi nízké odtoky z povodí Labe (obr. 5).

Havranský rybník na Mrlině byl patrně přeměněn na bažantnici asi roku 1717. Sousední Vyklecký rybník byl doporučen roku 1737 ke zrušení [22]

\section{OBDOBí 1745-1769}

V období 40. až 90. let 18. století se dostáváme k samotnému jádru problému, který souvisí s novými postupy v zemědělství. Od poloviny 18. století privodily některé př́rodní katastrofy (např. zemětřesení v Lisabonu 1755) a nepřízeň počasí podle německého historika W. Behringera [40] trhliny v dosavadním př́močarém optimismu osvícenských náhledů a vizí budoucnosti. Pro nás je důležitý přelom let 1739/1740 s neobyčejně tuhou a dlouhou zimou a povodněmi. Zámrz vodních ploch včetně např. Bodamského jezera svědčí o neobyčejně tuhé zimě. Pražský měštan F. V. Felír (1701-1757) uvádí [41]: „led na řece Moldavě přes 3 lokte [přes $180 \mathrm{~cm}$ ] i také více. Místama Moldava na mělčině až do gruntu vymrzla" [41]. Jak bylo zmíněno, právě hluboké promrzání rybníků působilo na Poděbradsku a Nymbursku mělkým rybníkům značné problémy.

Rok 1746, se řadí mezi katastrofálně suché, značka minimálního vodního stavu je vyznačena i na kameni v Děčíně (obr. 6). Sušší období a pokles vodních stavů Labe v době od roku 1761 až do roku 1766, i když značka minima $\checkmark$ Děčíně se nedochovala, je patrný z průběhu ročních minim vodních stavů $\checkmark$ Magdeburku (obr. 5). Právě v roce 1763 je zmiňován s ohledem na tuhou zimu špatný výlov rybníka Blato, kdy bylo vyloveno oproti násadě méně o 112 kop kaprů. Možná už tehdy těmto velkým rybníkům „začala zvonit hrana”. Podle J. Veverky [23, 24] ale existovaly velké rybníky napájené kanálem od Mrliny z Křince jako Havranský, Dolívka a Vyklecký ještě v roce 1768. Stejně jako dalších 12 rybníků se ale již rybami neosazovaly.

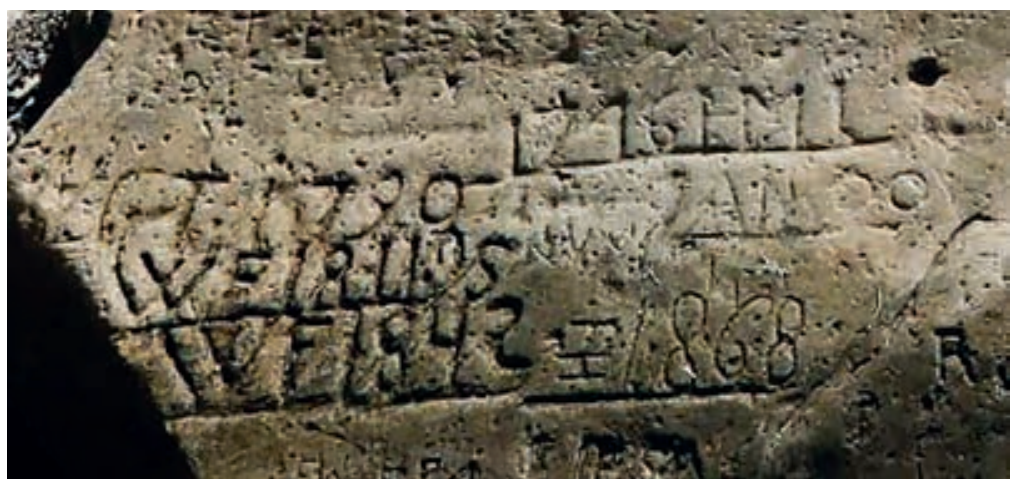

Obr. 6. Hladový kamen v Děčíně se značkami minim vodních stavů, zde v detailu roky 1746, 1790, 1800, 1811, 1842 a 1868 (klesající tendence 1746-1868 je dobře zřetelná i na sestupném razení minimálních vodních stavů)

Fig. 6. The "Hladový kámen" stone in Děčín with low water levels marks shows details of marked years of 1746, 1790, 1800, 1811, 1842 and 1868 (the decreasing tendency is obvious from descendant order of yearly marking)

\section{HOSPODÁŘSKÉ REFORMY A EXTRÉMY POČASÍ LET 1769-1787}

Často se zdůrazňuje role chladných, neúrodných let 1769-1772 a souběžných dopadů (neúroda, hlad, nemoci atd.). Navíc někteří autoři [1, 3] upozorňují i na fakt, že tato krize byla propagandisticky zneužívána. Argumentace byla namířena často právě proti rybníkưm, kterým byl přičítán podíl na vlhkém a chladném počasí. Bylo to stejně nespravedlivé jako přehánění pozitivního účinku rybníků a jejich vlivu na lokální srážky.

Tereziánské a Josefinské reformy vedly k četným změnám. Roku 1775 došlo k úpravě roboty "Robotním patentem", rok 1781 přinesl „Patent toleranční a "Patent o zrušení člověčenství, tedy nevolnictví. Představy o moderním hospodářství byly inspirovány, jak se někdy uvádí změnami v Anglii. Propagátorem u nás byl např. K. Zinzedorf (1739-1813) prosazovatel hospodářských reforem F. A. Raab (1722-1783) a také rada A. Koczian [3].

Milčický F. J. Vavák (poloha Milčic vyznačena na obr. 3) komentoval události v široké oblasti Poděbradska. Komentuje již zmíněné období 1769-1771 a překvapivě uvádí suchou periodu, a to již roce 1770 [8]: „Zajisté oblíbilo se Pánu Bohu českou zem potrestati, nebo pro to jarní mokro, potom pro sedm neděl trvající sucho velmi veliká byla všech věcí neouroda." V roce 1771, jarní sníh, deště a sucha vedly k špatné úrodě: „Po tom sněhu opět pole tak se rozkvasila a rozmokla a vnitřní vodní žíly se zdvihly, že zase velmi dlouho jarní setí trvalo. K tomu pršelo jednak přes celý duben až do 5. máje... Mezitím byl převeliký nedostatek v píci dobytčí; jeden centnýř sena byl za 1 zl. 30 kr., jeden mandel žitné dlouhé slámy za 2 zl. V některých vesnicích došky se střech trhali a na řezanku řezali, jakož pak mnoho statků jest viděti docela otrhaných... Od 5. máje až do 2. června nepršelo a časy byly tak prudké a horké, že zas hrozná suchota začínala býti; žita nemohla dobře růsti, jakož i zaseté ječmeny nemohly vycházeti a právě všecko smutno bylo v polích vidět." Nedostatek vedl podle Vaváka [8] k obecnému rabování obilných zásob, jehož předmětem byly i dva mlýny právě na Sánském kanále: „15. máje, před sv. Janem Nepomuckým tu noc z vesnic Odřepes, Chotánek a Libice všickni vesměs lidé událi sobě kvalt neb bouřku na Nový mlýn u Odřepes ležící, v něm co obili mlynářového zastihli, všechno vzali, jakož v druhém mlýnku (mlýn Mlýnek viz obr. 3) opodál od tohoto stojícím a témuž mlynáři patřícím." Situaci dále zhoršily červnové deště a následné povodně. Na obr. 5 je zřetelné (řada ročních minim vodních stavů Magdeburg), že období sucha 1761-1766 a 1781-1811 jsou zřetelně oddělena právě epizodou kolem roku 1771. Jenže poklesová tendence začíná inned roku 1772. F. J. Vavák zmiňuje suché periody i v roce 1774, 1775 a rozsáhlejší sucha 1776, 1777, 1779 a $1780[8,9]$.

$\checkmark$ roce 1773 byla zrušena podle F. J. Vaváka [7] soustava rybníků lichtenštejnského panství na blízkém povodí Šembery (viz dále). Po selském povstání roku 1775 potlačeném u Velkochlumeckého rybníka (2 ha) zmizel následně nedaleký rybník Rutvas (odhad 2 km²), který byl Kinskými parcelován na pozemky údajně z obavy z dalších revolt [42]. V roce 1777 zmiňuje F. J. Vavák další selské bouře. Zejména však popisuje chladný a velmi nezvyklý průběh jara a léta, a to až do července. $V$ srpnu ovšem zaznamenal obrat: teplo a sucho $v$ srpnu a zejména v zárí: „Hned po tom svátku [narození Panny Marie 8. 9.] začala být veliká tepla a parna, orat na setí se nemohlo pro sucho. Čekali jsme na déšt, ale nedočkali jsme ho; vždy pořád veliká parna, jako ve žni bývají, byla." Možná proto byl roku 1777 rybník Blato napuštěn jen z 1/3 (obr. 7) a jen na jedno "horko“ tedy na rok [21].

Při zaměřování pozemků se v roce 1776-1777 účastnil i F. J. Vavák [9]. V rámci map prvního vojenského mapování, se kterým tato práce souvisela, již nejsou vyznačeny velké rybníky u Rašovic: Vyklecký a Havransko. Z horní trasy Vesteckého kanálu tu zbyl jedině menší Podchotučný (Podchotucký) rybník, který sloužil jako „nadýmač” pro stejnojmenný mlýn u Křince (obr. 3). Novému mlynáři bylo uloženo v roce 1775, že [29]: „... na 3 léta spustí a bude osívat, aby se rádně od porostu rákosového a bláta vyčistiti mohl... [rybník tedy byl vypuštěn do roku 1778, pozn. autora]". V prvním vojenském mapování je vyznačena 
140
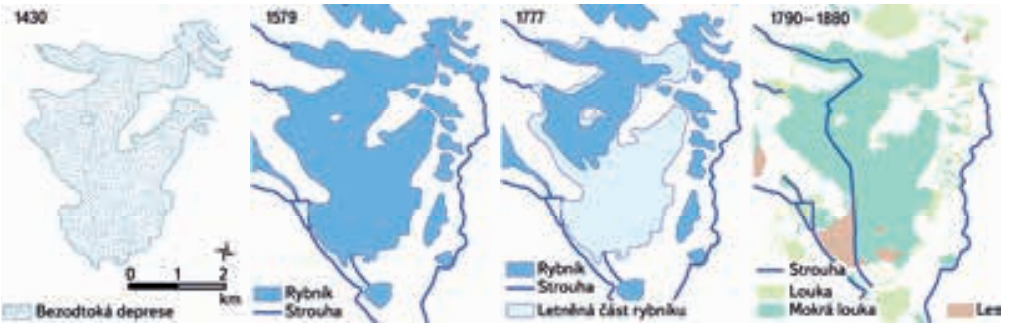

Obr. 7. Zjednodušený vývoj soustavy rybníka Blato: od období husitských válek, cca 1430 zde byl nebeský rybník, či prostě blata v bezodtoké oblasti, 1579 dokončená funkční rybniční soustava, 1777 naplnění Blata jen ze 30 \% (možná rekonstrukce), 1790-1880 období vypuštěného Blata, období "louky Blato" (rozložení luk podle stabilního katastru) Fig. 7. Simplified development of Blato fishpond system: the swamps and/or area without drainage was on this place prior year of 1430, the fishpond system was finished in year 1579, the fishpond Blato was filled only by $30 \%$ of volume (our estimation of the flooded area) in year of 1777 , the fishpond Blato was launched in year if 1790 , the fishpond Blato transformed to pasture and meadows in years between 1790-1880

z našeho hlediska velmi stará, zcela přímková trasa Mrliny pod Vestcem. Není vyloučeno, že tato zajímavá stavba je totožná s výše zmíněnou úpravou z roku 1658. Staré odstavené meandrující koryto Mrliny zůstalo na levém břehu a bylo podrobně zaměřené ještě ve stabilním katastru (není vyznačeno na obr. 3) a částečně se dochovalo dodnes.

Popis horkých dnů a sucha v roce 1781 a časných žní (kolem 15. července s jejich koncem do 22. července) se mísil ve Vavákově podání s komentář k Tolerančnímu patentu, averzi k nekatolíkům a procesím za déšt [9]: „Minulého roku v čas tak ukrutného a smutného sucha žádnému se z nich nelíbilo ke křriži jití a tam se za deštíček modliti... Až do 14. června každý den ráno zima ostrá, potom pak parna a sucho veliké začínalo býti, některý den i mrazy šedivé byly 14. června deštíček žádoucí prišel, ale jen místy toliko a u žádné vsi na všecka pole nepršelo. Odpadlci, tj. [Vavák užíval výrazy odpadlci, odpadlice, odpadlí od víry prípadně bludaři pro obyvatelé vesnic, kteří se přihlásili k nějaké formě evangelictví, pozn. autora] opovážili se mluviti, že proto neprší, že jsme všichni od katolické víry neodpadli. Když pak tento déšt priš̌̌l, chlubili se, že prý oni ho vyprosili. Nu, pozoruj každý, jaké jest to hovadství. Když jsme pak my ke kříži na modlení za deštíček chodili a nemajíce nyní kříz ve vsi, musili jsme k tomu za ves choditi, oni se nám jen toliko smáli a že s nedvědy chodíme, pravili“" [skutečně jde o výraz nedvěd (dnes medvěd), mínilo se tím asi, že chodí mimo obec, přeneseně tedy do lesa s medvědy, dnes už v Milčicích kř́ǐ̌ je, a to právě před statkem F. J. Vaváka, pozn. autora]. Podobně najdeme zprávy o suchu i roku 1782 (obr. 5). Značka minima vodního stavu Labe v Děčíně se nedochovala, zůstala ale na podobném kameni v Pirně.

Osud velkých rybníků v povodí Mrliny jako byl Chlebský, Bobnický, Draho (obr. 3) atd. možná ovlivnilo také další nepř́iznivé období 1783-1785, pozoruhodné po mnoha stránkách. Velká erupce vulkánu Laki ovlivnila na dlouhou dobu počasí a přinesla četné extrémy: od sucha, tuhých zim, povodní až po epidemie, jak bohatě dokumentuje odborná literatura [např. 40, 38]. Ještě za kruté zimy 1783/1784 ovšem podle Vavákových pamětí [10] rybníky existovaly: „Rybníky $v$ ten čas mnoho práce daly. Ryb onde i onde mnoho se zdusilo. Do prosekaných prohlubní valně ryby šly, že se snadně loviti mohly. Na zdejši poděbradské rybníky z celého panství lidé (z lásky) na prosekávání prohlubní a shazování sněhu na hromady choditi musili. Od nás z Milčic na Křečkovském rybníce dvakráte jsme byli."

Ovlivnil hluboký zámrz a úhyn ryb a následné suché léto 1784 (jistě s malým průtokem v Mrlině i Cidlině) rozhodnutí zrušit polabské rybníky, které se staly na čas spíše břemenem než zdrojem zisku? Důvod k rozhodnutí vypustit rybníky u Nymburka kromě získání půdy pro imigranty ze Slezska a domácí zájemce vlastně neznáme. Vavák [10] píše: „Na zdejším poděbradském panství čtyři hlavní rybníky zrušené a k užívání orním lidem propuštěné jsou tyto: Chlebský,
Bobnický, Draho a Křečkovský, dle čehož pod datum 28. července prohlášeno jest, kdo chce tam na svůj náklad stavěti, že hned začíti a před všemi emigranty, již ze Slezska sem běží, předek [přednost, pozn. autora] míti má." Půda byla přislíbena hospodár̆ům, kteří odešli patrně z konfesních důvodů do Slezska ještě kolem roku 1750, jak uvádí v dějinách Poděbrad E. Šmilauerová [43]. Nabídku (Guberniální nařizení z 6. května roku 1784) na novou půdu slezští evangelíci ale nevyužili. Půdu vypuštěných rybníků obsadili místo nich někdy slezští katolíci, tedy německy hovořící osadníci. Ti území původního ostrova uprostřed Bobnického rybníka osídlili ještě v době, kdy rybníky nebyly zcela vypuštěné. Dnes se tu nachází obec Kovansko.

V následujícím roce 1785 F. J. Vavák [10] popisuje výhled z Oškobrhu od poutního kostela na rybníky u Poděbrad: „K straně západní ... Item všecky hlavní poděbradské rybníky, obzvláště onen rozhlášený, Blato rečený, leta 1475 od Hynka knížete Minsterberského, Jiř́ho krále syna a pana na Poděbradech, udělány... toho místa Lustdorfu málo níže, asi 10 honův, stojí chápě neb chalupa při řece Cidlině panská, kdež jest Cidlina přehražena, odkudž širokým náhonem neb kanálem běží voda do rybníka Blata a několika jiných hlavních rybníků poděbradských. To a mnohem více a velmi vesele od kostela prv pověděného se spatř́, jakož i také celé poděbradské panství." Soustava rybníka Blato tehdy tedy ještě existovala.

\section{KOMENTÁŘE MILČICKÉHO RYCHTÁŘE F. J. VAVÁKA K RUŠENÍ RYBNÍKŮ V LETECH 1788-1799}

O tři roky později roku 1788 se začalo s vypouštěním a následným osetím Křečkovského a pravděpodobně také dalších rybníkủ. F. J. Vavák oceňuje zprvu velkou úrodu téhož roku [11]: „Toto ještě přisadím: Když tak nyní onde i onde množství rybníků se ruší a místo nich pole se vzdělávají, na takových rybnících letos znamenitá ouroda obilní lidi potěšila. Bohu díka!"

Roku 1790 jmenuje F. J. Vavák plodiny pěstované na dnech vypuštěných rybníků (len, konopí, zelí, ječmen, pšenice, oves) [11]: „Když pak těchto let onde i onde v zemi takměř na každém panství rybníky se suší a obilím zasívají, ten nálezek [vynález] obzvláště letos veliký užitek přinesl; nebo na takových osetých rybnících hojně obilí všech druhův se naklidilo; pakli na některém ne hojně, aspoň přece než se na polích vice, nebo po 1 strychu [0,315 ha] místem 8 i 10 mandel [mandel = 15 snopů, tedy asi 380-476 snopů z ha] pšenice a ječmena, též ovsa dosti dobrého sklidilo se. Iny, konopě, zeli, řepy, (zemáky) atd., vše na rybnících zrostlo a užitek přineslo."

Poukazuje ale na přítomné sucho a na rizika a stíny nového "nálezku“ [10]: „Tolikéž na našem panství poděbradském na druhé straně za Labem na několika suchých a zasetých rybnících hojnou ourodu lidé dostali, obzvláště v ječmeně a v ovse, tak že nyní s touto drahotou zištni jsouce, z toho přítomného sucha ne tak se rmoutí, jako těší; nebo ovšem kdyby třebas dva jen silné deště byly príšly, na mnohých rybnících ta ouroda by nebyla [tady mínil F. J. Vavák bohatou úrodu, která s ohledem na panující nedostatek a vyšší ceny, byla proměněna na značný zisk; mezi rádky tu lze ale číst i odsudek výdělku získaného s rizikem a také radosti, jejiž podstata byla trochu sporná, pozn. autora]."

$\checkmark$ roce 1791, již v dubnu, došlo na srocení několika set lidí v Poděbradech u zámku. Ti se dožadovali mimo jiné i parcelace rybniční půdy [12]. Zatím Vavák už spojoval příčiny (jak dnes říkáme hydrologického) sucha 1790 a 1791 s vysušením rybníků [12]: „Příčina suchých tak potoků jest i ta, že všecky vrchnosti již tomu, aby své rybníky raději obilím nežli rybním ziskem užívali. Protož z většího díla všude rybníky suché a obilím zaseté jsouci, ovšem hojné ourody vydávají, ale voda nemá nikde schránku k postání svému, prameny, od nichžto se potokové začínají, břehové suchotou vypijí, deštová voda inned odběhně, a tak zajisté, a tak rybníkové nejen pro ryby ale i k potřebě - mletí obilí - velmi platné jsou." 
Tráva z vypuštěného Blata byla téhož roku prodávána „na stojato“ sedlákům [21], 1 měřice (1 918 m²) za 20-30 krejcarů [Kreuzer, mince s kř́žem, přitom 60 krejcarům odpovídal jeden zlatý, v té době to byly krejcarové mince Josefa Il. anebo Františka II., pozn. autora]. Roku 1791 popisuje F. J. Vavák nalezení vykládané truhly na dně tehdy již vypuštěného a osetého velkého Křečkovského rybníka (obr. 3) [12]: „25. dubna v den Sv. Marka, děvečka jedna ze vsi Křečkova na panství poděbradském trhajíc trávu v obilí, kteréž jest na tamním velikém rybníce, jenž 3 léta se sušší a osívá [byl tedy od roku 1788 vypuštěn, pozn. autora], nalezla pikslu velmi drahou." Ta se ztratila $v$ průběhu honu na kachny, který se tu konal roku 1746 (viz výše sucho 1746) za účasti císaře Františka (manžel Marie Terezie). Na nalezení vzácné císařské tabatěrky, tedy oné „piksly“ byla vypsána odměna (8 dukátů „in specie“). Rybník pak byl vypuštěn (1746) a přikázána robota na její hledání.

Náhlé rozšíření výměry polí přineslo v roce 1792 organizační problémy [12]: „... ač dne 9. Juli začaly se veřejně žně, ale málo lidu na práci šlo. Př́ičina jest, že vrchnosti majíce své rybníky zaseté a robotu menší než bývala, mnoho lidu spotřebují a do kraje na žeň jíti jim nedají. Protož nouze o žence nemalá byla, že z toho nedostatku, kdo jaké dostati mohl, po 6 i po 7 krejcařich od záhona platil“.

$\checkmark$ roce 1793 bědoval F. J. Vavák znovu, tetokrát nad vysokou cenou ryb o Vánocích, kterou prodražilo zrušení rybníků [12]: „V takové přebídně zlo-cestní forotě ryby k Štědrému dni byly, jsou v drahotě, nebt' jich tak na mále skrz rybníků setí, ted pak pro ně dále nemohlo se jeti. Tř́liberních kaprů při mnohém výsadu 1 libra se platila za 8 krejcarü“ [12]. Konečně nastal i problém s tehdejším jediným chladicím médiem, totiž ledem a jeho dovozem. Po zrušení rybníků na Milčickém potoce uvedl F. J. Vavák [12]: „A poněvadž všecky 3 rybníky tatecké z nichžto se prve led brával, nyní suché jsou, protož nejbližší cesta pro led do Radimě se zapsala, a sice 3 míle anebo 3000 sáhů rakouských."

F. J. Vavák komentoval i doprovodný jev, úpadek odborných znalostí rybníkářů, a to při lovení rybníku Domku v roce 1793 [12]: „Letošní lov jeho byl od posledního v 10 letech; 8 let se obilím zasíval a 2 léta seděl [osíval se tedy $v$ letech 1783-1791]. Zatím ti, jenž tomu lovu rozuměli, vymřeli a protož nynější lovcové byli nevědomcové, odkudž lov se prodlil."

Není zcela jasné, jak dlouho ještě vydržely menší rybníky kolem Blata, jisté ale je, že teprve roku 1795 byl vypuštěn asi poslední z těch opravdu velkých, třísethektarový rybník Šumbor. Rybník Blato je toho roku zanesen již v mapě jako majetek vojenského hřebčína pronajatý za 5000 zl. ročně [22].

\section{DALŠÍ VÝVOJ OBLASTI V LETECH 1795-1880}

$\checkmark$ roce 1812, tedy 17 let po vypuštění velkých rybníkůa po velkém suchu roku 1810 a 1811, popisuje Vavák komisi, která 1. července vyšetřovala situaci na Šembeře (povodí Výrovky) v Poříčanech a později vyměřovala úpravu koryta a nový most u Třebestovic [7]. Komise inspektorů z Jičína, Poděbrad a Prahy byla svolaná na 1. července 1812 inspektorem černokosteleckého (lichtenštejnského) panství, přesně rok po př́valové povodni Šembery (30. června 1811). Vavákova kritika a nabádání se týkaly zrušení rybníků u Kostelce nad Černými Lesy. F. J. Vavák zde uvádí (a mapou dokladuje!) 30 rybníků na Šembeře zrušených či opuštěných roku 1773. Poznamenejme, že majitelka panství Marie Terezie, vévodkyně Savojská a Piemontská, rozená z Lichtenštejna (1694-1772), mezi lidem oblíbená a známá jako „Cafojka“, již tehdy nežila. V tomto velkém rušení byla patrně nevinně. Vavák k tomu zapsal do své kroniky [7]: „potok jenž U Šembery slove, jak na svém tahu, tak na ratolestech svých do 30 rybníků, z kterých žádný nesedí a vody v sobě nemá a všecky pusté jsou, protož jak sněžná, tak deštová voda nemajíc se kde zadržeti společně kvaltem teče a škody působí, čehož prve, než rybníky se spustily, nikdy nebývalo, a že by kníže Lichtenštejn z těch rybníků ještě větší užitek měl, než má nyní, když by v čas sucha i tu vodu mlynárưm, jako prve bývalo, prodávati mohl. Nebo tu z toho všeho okolí v čas sucha - ačkoliv jest asi 15 mlejnů - musejí lidé na Labe obilí voziti, když ty potoky přeschnou."
Poznamenejme i, že problém s nedostatkem provozuschopných mlýnů nejenže musel trvat, zvětšením výměry polí na místech velkých rybníků se pravděpodobně ještě zhoršil. Rybník Blato byl ale výjimkou. Na bývalém ostrově byl zřízen vojenský hřebčinec, který zde ale vydržel jen do roku 1818. Regionální literatura [44] uvádí, že kyselé rybniční bahno nebylo vhodné pro jakostní trávu a tvrdé ostřice nebyly vhodnou pastvou pro hřebčín.

$\checkmark$ roce 1821 byl postaven poslední mlýn na Sánském kanále, a to $\vee$ Pátku [17, 23, 24]. Byl to první mlýn pod bývalými nápustnými stavidly pro rybník Blato. Pravděpodobně s ohledem na využití podstatné části průtoku Sánského kanálu totiž žádné mlýny pod výpustnými stavidly až do zrušení rybníků nebyly. Na místě někdejších rybníků byly později zřízeny velkostatky Blato, Šumbor, Havransko atd. Blato se však polem nestalo. Na mapách stabilního katastru a druhého vojenského mapování vidíme pastviny. Blato se tak stalo znovu „blatem" anebo rozsáhlou pastvinou s mokrými loukami (obr. 7) a zůstalo jím ještě dlouho.

Můžeme zde zmínit jeho další rozměr, totiž jeho užití jako svébytné retenční nádrže s objemem cca 20 mil. m³. V době katastrofální povodně na Labi, která nastala pouhých 10 měsíců po známější povodni koncem března roku 1845, se totiž Blato znovu naplnilo. Ve čtvrtek 29. ledna konstatoval list Bohemia (č. 14/1846 z 1. února), že „město Poděbrady je čtvrtý den pod vodou. Hladina dosáhla úrovně, kterou ani nejstarší lidé nepamatují. Ulice a cesty jsou na mnoha místech protrženy, mosty odplaveny..." (pưvodní překlad z němčiny). Těžce byly postiženy obce Polabec, Zboží, Kluk, Libice a části vlastních Poděbrad. Jen s velkými těžkostmi mohli obyvatelé zachránit nářadí, dobytek či životy a nový řetězový most byl v reálném ohrožení. V novinách se dále psalo: „Labe stálo o plné 2 střevíce $(60 \mathrm{~cm})$ výše než za strašné povodně v roce $1845 \ldots$ tedy co do výše, rozsahu i trvání byla letošní povodeň horší. Právě tato úroveň je nejvyšší zaznamenanou povodní v Poděbradech na inundačním mostě, výška vody dosáhla asi 450 cm nad nulou vodočtu [45]. Další rozbor této katastrofální, a dodnes zdaleka nepřekonané, středolabské povodně je stále velmi žádoucí.

Autor dalšího článku $v$ deníku Bohemia hovoři o možnosti nové oblevy, která by mohla inned Jizeru, Jizerku a také na vodu chudou Cidlinu (!) donutit znovu vystoupit ze břehů. Podobnými malými prítoky se (podle něj) zcela zaplnilo již více než 80 let (ve skutečnosti asi 56 let) vysušené Blato (v originále „Blatossee") na panství Poděbrady (Bohemia z 27. 2. 1846). Je pravděpodobné, že Blato se naplnilo tak rychle př́tokem Sánským kanálem prostřednictvím Cidliny a možná i odpadními kanály z Mrliny přes bývalý rybník Šumbor.

Výjimečné svědectví o několik let později podává B. Němcová (1820-1862), a to za svého pobytu v Nymburce (1848-1850), když píše A. Fričovi (1832-1911) [46]: „Močariny po vlhkých lukách obrostlé jsou sítinou a povrch vody pokryt je širokým listem vodní růže [leknín, (Nymphaea), pozn. autora] a drobnolistou lemnou [okřehek (Araceae), vodní rostlina s drobnými lístky, pozn. autora]. Po lukách pasou děti stáda krav, černé, rezavě bílé a šedé barvy, na nichž viděti dobré chování. Selské domky s dřevěnými podsińnami [předsunutý štít stínící průčelí domu, ještě dnes častý a typický znak lidové architektury Nymburska, pozn. autora] a štítami slaměnými střechami bělí se uprostřed sadů ovoce již zbavených. Po návrších viděti háje březové a borové, okolo kostelíčků leporosté kmeny jasanů, mohutné duby a krásné lípy, jichž ožlutělé listí větřík střásl a po rovině roznáší."

Další rozměr Blata byl tedy krajinářský ale také botanický. V řadě odborných pojednání z 19. století jsou totiž spojeny nálezy někdy dnes vzácných bylin s fenoménem "Blatowiese“ a také jménem tehdy nejvýznamnějšího českého botanika F. M. Opize (1778-1858) a také L. J. Čelakovského (1834-1902). Tento charakter si udrželo Blato, na rozdíl od parcelovaných rybníků na Nymbursku, nejméně do 60. a 70. let 19. století. Je jisté, že z dnešního hlediska by byl lučinatý ekosystém mokřadů a luk přinejmenším stejně významnou lokalitou jako NPR Bohdanečský rybník (ČR č. 451/2005 Sb.). 
Vypouštění rybníků pokračovalo u nás ještě po celou polovinu 19. století. Důležitou osobností byl zde A. Wittman (1770-1842), propagátor rušení rybníků a realizátor meliorací. Na sklonku života působil ve službách Schwarzenbergů. Zemřel paradoxně právě $v$ roce, který se zapsal do dějin jako nejsušší rok $\vee 19$. století. Právě v tomto roce 1842 se otázka sucha znovu dostává do popředí zájmu.

Následující období, zejména 60. a 70. léta 19. století, znamenala částečné přehodnocení funkce rybníků. $\vee$ diskusích, kde se v katastrofálně suchém roce 1874 zvažovaly přičiny sucha a adaptační opatření, se hovořilo o zalesňování a obnově rybníků. Později, v zemském sněmu v roce 1875 padl návrh k desetiletému odpuštění daní při obnově anebo zal ožení nových rybníků. Vrchnístavební rada místodržitelství Ing. V. Hlásek kritizoval na setkání v lednu 1875 vysušování mokřin a rušení rybníků (Leitmeritzer Zeitung, leden 1875). Vodohospodářské potíže, zejména zrychlení odtoku a nízké vodní stavy prričetl i kácení lesů a četným melioračním drenážím. Ve velkých rybnících viděl V. Hlásek přirozené regulátory odtoku a vyzval k zachování a k jejich obnově. Produktem všech těchto debat se nakonec stala, mimo jiné, hydrografická komise Království českého založená roku 1875. Ta měla vytvořit pozorovací sit vodočtů a srážkoměrů a objasnit na základě pozorování objektivnější pravdu o suchu. Ve stejném období působil již nejvýznamnější novodobý rybnikář Josef Šusta (1835-1914), jehož zásluhou řada třeboňských rybníků naopak zrušena nebyla.

V rámci velké regionální povodně v únoru 1876 způsobila i Mrlina velkou záplavu (Národní Listy, 8. 3. 1876). Lokální, zhoršující príčinou byla nedostatečná kapacita nového mostu Severozápadní dráhy (budována 1869-1875) přes Mrlinu u Nymburka.

\section{OBDOBÍ ODVODŇOVÁNí 1883-1958}

Radikální změnu přinesly meliorace, tj. regulační projekt Mrliny prosazený správcem velkostatku Poděbrady L. Doležalem a podpořený zemědělskou radou. Počátkem byla terénní prohlídka z 26. 1. 1883. Projekt po přezkoumání vyšel v zemském zákoníku roku 1885 (XVI, č. 37). Za pozornost stojí fakt, že projekt zpracoval za zemědělskou radu Ing. Boleslav Trojan. V príležitostné publikaci píše L. Doležal: „Po staletí byly oba tyto naše okresy těžce pronásledovány krutými vodními nehodami, jak toho v komorní knize z roku 1729 dočísti Ize. Jaký však rozdíl před stoletími a nyní! Jindy zaplavovaly dravé proudy a tiché zpáteční výtopy nazvíce jen pastviny a kyselá luka, povstalá z četných (rozsáhlých) vypuštěných rybníků; nyní však započalo se postupně s pěstováním stebelnatin a luštěnin, a kdy přistoupeno k zřizování nových hospodářských dvorů, a kdy na sklonku devatenáctého století veškeré pastviny ba i luka za příčinou intensivního pěstování cukrovky téměř napořád rozorány byly, zaplavována nadále širá pole s mnohoslibnou ano i bohatou žní." Hlavním cílem regulace Mrliny a melioračního projektu bylo rychlé odvodnění a pokles podzemních vod v daném území. Bylo pamatováno i na závlahy vybudováním pohyblivého jezu v profilu Chaloupky (který však nebyl místními rolníky převzat). Ochrana před povodněmi, která byla v úvodu zmíněna, byla projektována podle výšky únorové povodně roku 1876 (viz výše), kterou L. Doležal označil jako normální velkou vodu. Trochu zdrženlivé hodnocení protipovodňové ochrany vyplývá asi z faktu, že čerstvě regulovaná Mrlina způsobila několik měsíců po dokončení stavby, již za velké a známé povodně z 3. 9. 1890, mnoho škod (nejznámějším dopadem povodně je zkáza Karlova mostu o den později). Protrhla se hráz v Křinci, voda pak zničila dva domy ve Vestci úplně a asi 9 stodol bylo pod vodou, jak konstatoval místní pisatel a dodal: „K velkému žalu konstatovati se musí, že úprava Mrliny, jež přes 400000 zl. stojí a která takřka věčné břemeno rolnictvu uložila, nevydržela první obtěžkávací zkoušku, ukázalo se nyní, kde špatně bylo stavěno" (Národní Listy z 6. 9. 1890 a 28. 3. 1891). Opětně se Mrlina rozvodnila v rámci viny přivalových povodní i v květnu 1897 (Národni Listy 26. 5. 1897).
K drenáži bývalých rybníků Blata, Okřínku a Šumbora přikročil poděbradský velkostatek v letech 1890-1892. Další zlomysIností osudu bylo odvodnění Blata dokončeno v době extrémního sucha let 1892 a 1893. Právě tyto roky jsou mimo jiné vyznačeny i na hladových kamenech nejen v Děčíně, ale i jinde.

Po roce 1918 byla zakládána na Poděbradsku meliorační družstva, Mrlina byla zaústěna pod nový jez v Nymburce proto, aby se zvýšil spád hladin. V červnu 1926 se po silných deštích ve dvou vInách Mrlina znovu silně rozvodnila. Tato katastrofální povodeň, podobně jako na Klenici, byla zhoršena protržením rybníků. $V$ prípadě Mrliny to byly rybníky kolem Jičíněvsi a Kopidlna. Voda pak dosáhla výšky mezi 3-4 m a zatopila rozsáhlé oblasti mezi Rožd’alovicemi a Vestcem (Národní Listy č. 164 z 16. 6. 1926). Další silný déšt 17. 4.1928 vedl opět k rozvodnění, navýšení hrází Mrliny fošnami ale nakonec odvrátilo scénář roku 1926 (Národní Politika z 20. 4. 1928). Vlivem promrznutí Mrliny až ke dnu došlo za pověstné zimy 1929 k vytvoření bariér a lokálním zátopám u Malého Vestce (Národní Listy 22. 3. 1929).

Další meliorační vinu, která začala v roce 1938, přerušila válka. Po jejím skončení pokračovala do roku 1950 a znovu navázala roku 1958 [44]. Odvodnění blat shrnuji publikace ze 70. a 80. let 20. století $[44,46]$ následně: „... tam, kde za vlhkých let zbahnění pozemků bránilo rádnému obdělávání polí, kde počasí brzdilo včasné síje a násilně zkracovalo vegetační dobu, tam kde se ocitly znovu desítky pracovníků, aby na největší meliorační stavbě v republice dokázaly, že moderní technika dovede čelit nepřízni i tam, kde proti člověku se spojila príroda a následky staletí. Na poděbradských blatech vyryly bagry desítky kilometrů otevřených odpadů, které před tím vyrýsovaly ruce techniků... Staletý boj o vodu skončil vítězstvím člověka..."

\section{OBDOBÍ POVODNÍ 2001 AŽ 2013, PERIODA SUCHA A ZADRŽOVÁNÍ VODY V KRAJINĚ 2014-2019}

Po období s menší frekvencí povodní, kdy průtok Mrliny přesáhl maximálně hranici $40 \mathrm{~m}^{3} . \mathrm{s}^{-1}$ (povodně 1956, 1977 a 1979), přišly začátkem 21. století povodně mnohem výraznější, a to i zde na Mrlině. Šlo zpočátku o případ méně významný, $\checkmark$ roce 2001 (jen $\left.24 \mathrm{~m}^{3} . \mathrm{s}^{-1}\right)$. Série povodní na úrovni Q20-Q50 následovala v lednu $2003\left(60 \mathrm{~m}^{3} . \mathrm{s}^{-1}\right)$, dubnu $2006\left(67 \mathrm{~m}^{3} . \mathrm{s}^{-1}\right)$ a záŕí $2010\left(69 \mathrm{~m}^{3} . \mathrm{s}^{-1}\right)$. Vrcholem byla povodeň v červnu $2013\left(111 \mathrm{~m}^{3} . \mathrm{s}^{-1}\right)$ na úrovni Q100. Voda v různé míre zaplavila území u Vestce, asi částečně i na místech původních rybníků Havransko, Vykleckého a Kratonoského. Do rybníka Blato se voda tak jako roku 1846 pravděpodobně nedostala. Výšky těchto moderních povodní najdeme na mostě v Rašovicích, viz obr. 8

Nyní, od roku 2014 prožíváme naopak období katastrofálně malých průtoků. Průtoky Mrliny i Cidliny dosáhly v roce 2015 a 2018 v době letních minim úrovně desítek litrů za vteřinu. V kanálech, které sloužily napouštění či odpouštění rybníků a později melioraci a také $v$ dolní Mrlině, voda v létě prakticky neteče. Aktuální stav vede k úvaze, jak mohla vypadat podobná situace třeba v letech 1766, 1783-1784, 1790-1791 atd.

\section{DISKUSE}

\section{Blato po stránce vodohospodářské bilance}

Podle čísel, která platila v době existence Blata, jeho rozloha byla 2705 čtverečních sáhů, podle jiných měření 5122 měřic, to je 9,83km², průměrná hloubka cca 7 stop $(220 \mathrm{~cm})$ a maximální hloubka 10 stop $(310 \mathrm{~cm})$. Zadržený objem vody $\checkmark$ rybníku Blato můžeme odhadnout tedy asi na 20 mil. $\mathrm{m}^{3}$. Je potřeba si ale 
uvědomit, že celková plocha systému rybníků (Šumbor, Křečkovský, Hrádkovský, Budiměřický, Úmyslovický [jiný a více tradiční název rybníku, zohledňující i jeho tvar, byl Rohlík, ten se vepsal i do pomístního názvu lokality] atd. kolem Blata a na Mrlině, které zásoboval vodou Sánský kanál, se blížila 18,0km².

Při ztrátě pouhého $1 \mathrm{~mm}$ vody výparem za jeden den, kdy nepršelo, ubylo by v rybníku Blato o ploše cca $10 \mathrm{~km}^{2}$ cca $10000 \mathrm{~m}^{3}$. Aby se tato ztráta vyrovnala, muselo by do Blata celý den pritékat Sánským kanálem 0,115 $\mathrm{m}^{3} . \mathrm{s}^{-1}$. Pro bilancování vody v rybníce je dưležitý rozdíl mezi ročním výparem z vodní hladiny a ročním srážkovým úhrnem. Teoreticky je tato bilance mírně (-50 mm) anebo silně $(-200 \mathrm{~mm})$ záporná na velké části našeho území. Nejvýrazněji se projevuje v oblasti srážkového stínu severozápadních Čech a na jižní Moravě ale také v polohách pod 500 m n. m. (obr. 8).

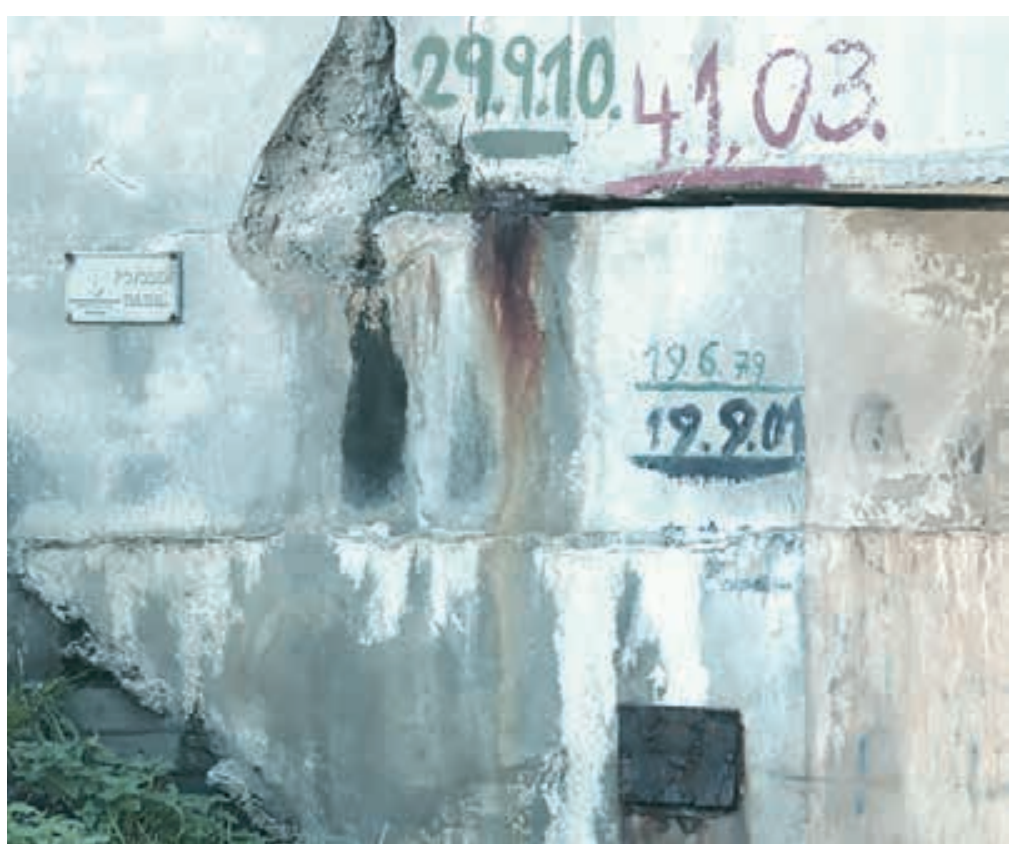

Obr. 8. Značky povodní Mrliny v letech 1979, 2001, 2003, 2006 a 2010 na pravobřežním návodním pilíri mostu v Rašovicích (nápis na spodní desce je nečitelný); chybí značka povodně z června 2013

Fig. 8. The flood marks in years 1979, 2001, 2003, 2006 and 2010 of Mrlina River on the right side of the pillar on the bridge in Rašovice village (the inscription of a the metal slab is unreadable)

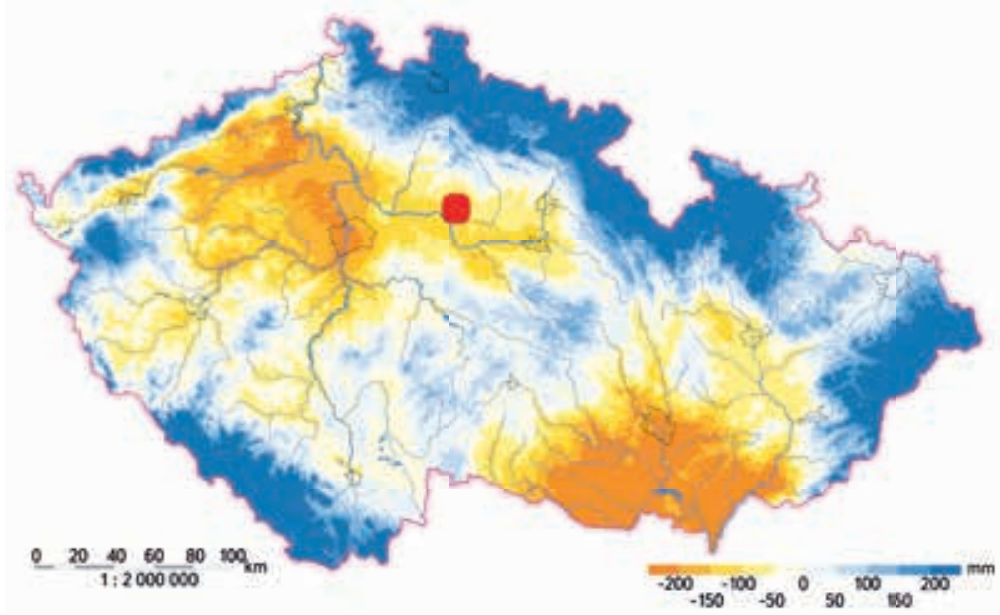

Obr. 9. Průměrná roční vláhová bilance, tedy dlouhodobý roční úhrn srážek zmenšený o teoretický výpar, podle atlasu klimatu Čech [43]; červeně zájmová oblast Fig. 9. The average annual soil water balance where the annual precipitation average is reduced by total evaporation; the area of interest in red
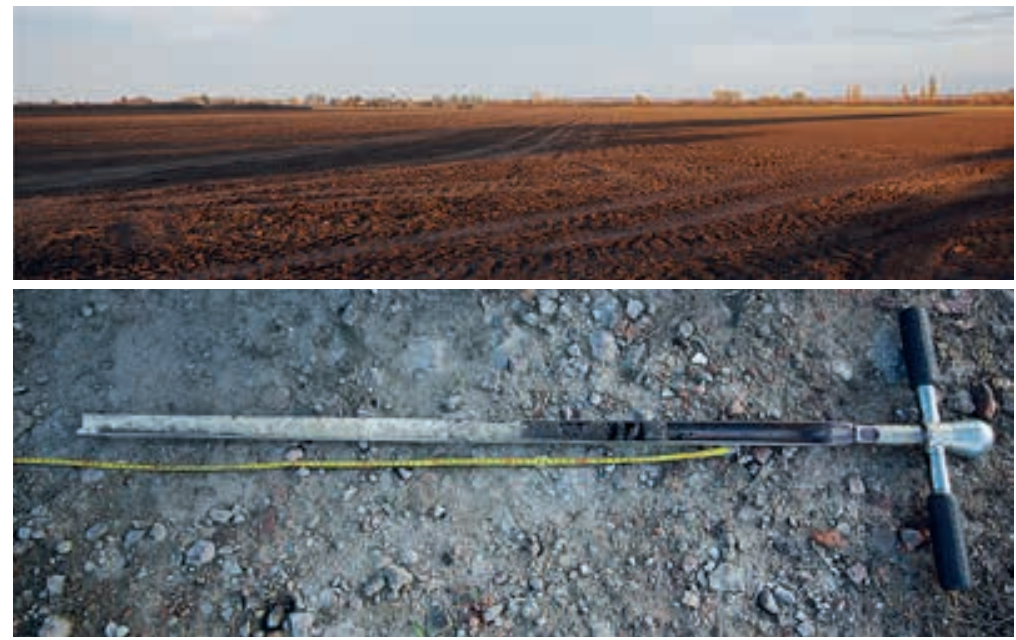

Obr. 10. Nahoře: Blato, bývalý ostrov Čejky, dole: odběr $40 \mathrm{~cm}$ ornice, zbytek $60 \mathrm{~cm}$ sprašový podklad; kromě prachové části také zrnka písku, tedy přepracovaná spraš, spolu s prípadným jezerním sedimentem; složení: cca stejná koncentrace Ca a Si (10-20\%), kromě toho cca $1 \%$ železa a hliníku; v pưdě (černozem) je méně Ca, více Si Fig. 10. Above: Former "Blato" pond's northward view from the former island Čejky, below: sampling of cca $40 \mathrm{~cm}$ topsoil, the rest represents $60 \mathrm{~cm}$ of loess/silt base; loess/ silt material occasional contains the sand, probably possible remnants of former lake sediment; ingredients: cca identical concentration of Ca and Si (10-20\%), cca 1\% iron and $1 \%$ aluminium; in soil (black earth) there is less $\mathrm{Ca}$, more $\mathrm{Si}$

Pokud vyjdeme z klimatického atlasu ČR [47], pak v průměru by ztráta vody $\checkmark$ oblasti Blata byla asi 100 až 150 mm ročně (obr. 9), k vyrovnání ztráty bylo by potřeba ročního průměrného př́toku $0,046 \mathrm{~m}^{3} \cdot \mathrm{s}^{-1}$. Dlouhodobý průměrný průtok Cidliny v Sánech je $5,2 \mathrm{~m}^{3} \cdot \mathrm{s}^{-1}$, pritom Sánský kanál by podle toho měl zabezpečit $50 \%$, tedy cca $2,6 \mathrm{~m}^{3} . \mathrm{s}^{-1}$. V průměrném roce není tedy problémem ztrátu výparem doplnit. $V$ prípadě suchého roku, asi jako roku 2018, kdy byla teoretická ztráta v této oblasti až -400 mm, šlo by již o nutný průměrný roční prítok $0,12 \mathrm{~m}^{3} \cdot \mathrm{s}^{-1}$. Bez dotace by tak teoreticky ubylo až $40 \mathrm{~cm}$ vody a chyběl by tak ročně objem asi 4 až 5 mil m³. Několik podobných let by patrně dokázalo vysušit celý rybník Blato, pokud by Sánského kanálu nebylo.

Tato možnost není zdaleka jen teoretická, stačí připomenout jinou mnohem větší vodní plochu Neziderského jezera. Je to 1-2 m hluboké jezero o ploše $315 \mathrm{~km}^{2}$ nedaleko Vídně. Jezero vyschlo $v$ posledních čtyřech stoletích přinejmenším pětkrát. Naposledy bylo zcela vyschlé v katastrofálně suchém období 1858-1878, přesněji řečeno bylo vyschlé mezi lety 1868 až 1876. Když bylo v roce 1875 vyschlé, psaly noviny i o povážlivém poklesu také u jezera Balaton (Posel z Prahy ze 4. 9. 1875). Neziderské jezero se naplnilo až za povodně v únoru 1876 (Posel z Prahy, 23. 3. 1876), kterou jsme zmínili již v souvislosti s Mrlinou. Úplné naplnění jezera nastalo až na konci suché periody 1858-1878, a to v roce 1878, kdy dosáhlo přibližně plochy z roku 1864 (Posel z Prahy ze 6. 4. 1879). K jeho vyschnutí došlo předtím v letech 1740, 1773, 1811 až 1813. O jeho vysušení uvažoval i výše zmíněný $A$. Wittmann, který prováděl meliorace a rušení rybníků naposledy na panství Třeboň.

Rybník tedy povrchovou vodu často spíš spotřebovává. Nemůžeme od něj očekávat nemožné, tedy nějakou výraznou dotaci průtoku bez újmy na jeho jiných funkcích. V příspěvku o výparu [48] je ukázáno, že nemůžeme čekat ani výraznější navýšení lokálních srážek vlivem výparu. Zároveň Ize ale z údajů z klimatického atlasu ČR [47] prokázat alespoň četnější výskyt srážek s denním úhrnem do 0,1 mm. Tyto skoro neměřitelné srážky mají ale svůj význam. Mlhy a usazené (horizontální) srážky mohou prospět alespoň bezprostřednímu okolí rybníků. Mưžeme tu nabídnout jistý pozitivní vláhový vklad alespoň pro louky a pastviny, které $v$ době sucha kolem toků a rybníků vypadají skutečně podstatně příznivěji než dále od nich. 


\section{Mohlo být Blato jezerní pánví či jezerem?}

Je možné, že původně bezodtoká oblast za Poděbrady, která byla prokazatelně rozsáhlými blaty a po 300 let rybníkem, byla pririrozenou vodní plochou, tedy jezerem? J. Veverka upozorňuje, že půda v oblasti rybníků se liší dodnes od okolních půd: „Různě složené usazeniny na dnech bývalých jezer a rybníků se ještě dnes liší od pưvodních okolních pưd a jsou svědectvím zavodnění v minulosti. Bývalé vodní plochy prozrazují zejména těžké půdy písčitých slínů, permských lupků a lehké půdy písčitých a stěrkových náplavưu [23, 24].

$\checkmark$ rámci třeboňské rybniční pánve v lokalitě současného rybníka Švarcenberk byly mezi Ponědrážkou a Veselí nad Lužnicí v 70. letech zjištěny pod vrstvou rašeliny jezerní sedimenty. $\vee$ nedávné době se podařilo kolem někdejšího jezera doložit také mezolitické osídlení [49]. Stárí jezerních sedimentů bylo určeno na 16000 let. Kromě značných nejistot ohledně mechanismu vzniku jezera je pravděpodobné, že jeho vznik souvisí s chladnějšími a vlhčími klimatickými podmínkami období konce poslední doby ledové.

Kolem Veselí n. Lužnicí i u Poděbrad se jedná o rozlehlou rovinatou plochu omezenou morfologicky, tak, že zde nemůžeme vyloučit při příznivé srážkové bilanci soustředění vody a vznik přirozených vodních ploch. Oblast jezera Švarcenberk je ve výšce cca 420 m n. m., poděbradské Blato je o 230 m níže ve výši asi 187-188 m n. m. a jeho břehy se pohybují na výšce 189-190 m n. m.

Velmi záleží na tom, zda se oblast Blata mohla dostat při povodních do kontaktu se zatopeným územím směrem od Cidliny či Labe. Za současných podmínek není Blato v dosahu aktivní povodňové zóny Labe. Předpokládáme, že za katastrofální povodně v roce 1846 bylo Blato patrně naplněno prostřednictvím Sánského kanálu. Protože $v$ Poděbradech tato největší labská povodeň dosáhla zřejmě kóty 188,5 m n. m. (asi 50 cm výše než roku 1845), nelze zcela vyloučit průnik vody z Labe při některých ještě významnějších povodňových prípadech. Charakter sedimentu by se pak ale asi nelišil od jiných zatápěných míst kolem Labe.

Podmínky $v$ období konce posledního glaciálu mohly být odlišné. Poděbradská blata jsou nejnižší částí kotliny, kde se na jeho konci pravděpodobně koncentrovala srážková voda a voda z tajícího permafrostu. Vytvořená kotlina pravděpodobně obsahovala mokriny a mělká jezera, ve kterých se tvořil jezerní sediment. V odebraných sondách bylo $40 \mathrm{~cm}$ ornice, zbytek tvořil materiál charakteru spraše (obr. 10).

\section{Obecné poznámky k funkci rybníků $v$ době sucha do 19 . století}

Rybníky jsou v souvislostech sucha zmiňovány zejména jako záložní zdroj energie pro vodní stroje, tedy zejména mlýny, pily, stoupy, sklárny aj. Příklady jaké výhody anebo nevýhody z existence rybníka plynuly, uvádíme na ukázkách ze suchých let 1642, 1698, 1810, 1811, 1835, 1836 a 1928.

V Krolmusově soupisu povodní a such je celá řada ukázek dokreslujících význam některých rybničních soustav v době sucha. V. Krolmus ze své vlastní zkušenosti zmiňuje suchý rok 1835 [6]: „Zle bylo v létě o melivo: potoky takořka vyschly a na řekách Mži, Ohři, Labi a Vltavě atd. bylo málo vody. Pod jezem každým suchou nohou malé dítě přešlo [pozoruhodný doklad o zůstatkovém průtoku, pozn. autora]. Sem a tam na Mži vodu mlynáři nadržovali. Lid 6 i 7 hodin cesty do mlejnů jezdil. Sem a tam vodu vrchnosti na rybnících za kolik tisíc zlatých mlynářům prodávali, k. p. Smečenská vrchnost za několik set ji prodala. Rakovnický Magistrát ji též prodal svým mlynářum..." Dojezdová vzdálenost k zpracování meliva byla tedy v hodinách (7-8 h) anebo v českých mílích, jak uvádí prí podobné situaci milčický rychtář Vavák [7] k roku 1810 a 1811 (asi 4-5 mil, 1 česká míle = 7,5 km, tedy kolem 30-37 km). V uvedených katastrofálně suchých letech jako 1811, 1835-1836, ale zejména 1842, byli zájemci nuceni dojiždět na velkovodní mlýny na Jizeru, Sázavu, Berounku a Labe, kde minimální průtoky klesají zcela výjimečně pod 2-3 $\mathrm{m}^{3} \cdot \mathrm{s}^{-1}$ (např. v roce 1904, 1947), př́ípadně na VItavu (neklesaly pravděpodobně pod $12 \mathrm{~m}^{3} \cdot \mathrm{s}^{-1}$ ) a Labe $\left(10 \mathrm{až} 30 \mathrm{~m}^{3} \cdot \mathrm{s}^{-1}\right.$ ) [40]. Na Poděbradsku zmiňuje Vavák, že "mleči" dojižděli někdy na mlýn Pamětník (na (idlině) ale $v$ době velkého sucha až na Labe. Podle něj běžely i labské mlýny $\checkmark$ době sucha roku 1810 a 1811 jen s nadržováním [7]. Spolehlivě je samozřejmě nemožné odhadnout průtoky Labe a Cidliny v těchto letech. Pokud předpokládáme podobnou situaci jako v nejsušších letech např. v roce 1904 [50], 1947, 2015 a 2018 (databanka ČHMÚ), pak Ize odhadovat, že se v Poděbradech a Nymburce mohl průtok Labe v roce 1811 pohybovat kolem $10 \mathrm{~m}^{3} . \mathrm{s}^{-1}$, průtoky Cidliny a tedy i v Sánském kanále mohly klesnout pod $0,1 \mathrm{~m}^{3} \cdot \mathrm{s}^{-1}$.

$\checkmark$ chronologickém sledu ukážeme dalši príklady téhož. Za velkého sucha roku 1642 měl na Boleslavsku problémy hejtman Vrutický, jak jsme uvedli výše s násilným spouštěním rybníků v době sucha. V roce 1698 správce Kalousek nadržoval vodu $v$ Jesenických rybnících na Rakovnickém potoce. Po prütrži mračen ale došlo k protržení rybníků, totálnímu vyplavení Rakovníka, které zde bylo ještě horší (podle míry zatopení náměstí) než při pozdější známé katastrofální povodni roku 1872 a škody na rybnících predstavovaly 2500 zl.

Podobný problém měl správce Šourek na Jetřichovickém panství o 137 let později, v již zmíněném velmi suchém období let 1835-1836: „Na Berounsku okolo vysokého Chlumce, Selce, Přestavlk a Prčic, nechtěl p. Šourek, zprávec na Jetřichovicích z rybníka Františka nazvaného, mlynářmm na potok vodu pustiti a prodati, aby lidé semleli; pročež se okolo Chlumce lid se sochory řetězy, sekerami, motykami, lopatami a nástroji rozličnými sešel, táhl od vesnice k vesnici, koho kde napadl, každý vše musel nechát ležeti, a s nimi táhnouti. V čele byl vůdce na koni, který zástup vedl k Selci a Prčicưm, městečkům, a až k rybníku Františku u Přestavlk... Na 600 osob se na hrázi rozložilo, jenž rybník skrze 14 dní hlídali, při ohni ležely, jedly a pily..." [6]. Nemusíme dodávat, že veškerou vodu z rybníka využili k semletí. Je evidentní, že voda v rybníce, či jezu byla v době sucha předmětem výdělku a někdy také sociálního napětí.

V suchém roce 1928 (je to i jeden z roků vyznačených na Hladovém kameni v Děčíně) zmiňuje Národní Politika z 5. srpna hromadné hynutí ryb na řekách a rybnících zejména $v$ jižních Čechách. K situaci se vyjádřil správce stanice Státního ústavu hydrobiologického ve Vodňanech prof. V. Štěpán (Štěpán Václav Josef, od roku 1897 profesor rolnické školy v Českých Budějovicích, později ředitel rybářské školy ve Vodňanech, narozen 24. 1. 1873, Velké Zamachy nedaleko Mšena, zemřel 5. 1. 1941, České Budějovice, http://encyklopedie.c-budejovice.cz/clanek/stepan-vacslav-josef). Podle něj mělo jít o důsledky velkého horka a nedostatku vody, kdy se šírila plíseň žaberní. Velké ztráty nastaly za nízkých vodních stavů, kdy řada rybníků nebyla pro nedostatek vody napuštěna, řada byla v začátku července 1928 vypuštěna. Očekávalo se, že majitelé rybníků budou žádat o odpuštění daně. Není dưvod pochybovat, že jiná nebyla ani situace na polabských rybnících v době uvedených významných suchých period 18. století. Velké rybochovné rybníky a rybniční soustavy mohly trpět nedostatečným prítokem a značným výparem z vodní hladiny, tím asi problematickou kvalitou vody. Ostatně několik novodobých príkladů z roku 2018 máme ještě $\checkmark$ paměti.

\section{Proč tedy rybníky zanikly?}

J. Veverka [27] použil spojení: „byla to jistě pozoruhodná soustava [myslel samozřejmě rybníky kolem Nymburka a Poděbrad] a zničili ji lidé, jejímž předkưm po staletí sloužila". Je to názor prírodovědce a nymburského rodáka, z něhož vyplývá zjevná lítost. Obě soustavy představovaly podle něj 17,4 km² rybniční plochy, která lemovala bezprostřední okolí Nymburka a Poděbrad. Pro J. Veverku byla snad předmětem jisté hrdosti ale zároveň i pocitu křivdy nad ochuzením místní krajiny o hladiny rybníků, které dnes začínají až v lesích kolem Vlkavy, Jabkenic, Loučeně, Rožd’alovic a Dymokur. 
Připomeňme některé důvody rušení rybníků, které se uvádějí v práci k tématice zaniklých rybníků [2]:

- hospodářské inovace (strî́davé hospodaření, zavádění nových plodin),

- technické inovace (nástup parních mlýnů v 19. století),

- technický stav rybníka a finanční možnosti, představy a schopnosti majitelů, např. po živelných pohromách, velkých dějinných zvratech a jiných ničivých diskontinuitách anebo jen pouze vlivem špatného hospodaření,

- nízká prestiž rybníkářství (dobové náhledy a trendy).

Všechny dưvodu mohly platit zároveň anebo zvlášt', anebo některé možná chybí? Hydrologická a meteorologická data napovídají, že právě suché roky 1719, 1726, 1746, 1761-1766, 1781-1783, 1790-1794, 1800 a 1811 prohloubily propast mezi rychlými výnosy z polí a tehdy problematizovaným rybníkárstvím. Kombinace tuhých zim s hlubokým promrzáním rybníků a sucha, typicky v roce 1784 a 1785 přinesly další zátěžovou situaci. Ukázali jsme, že rybník Blato nemohl prosperovat bez Sánského kanálu. Ztráty výparem musely nastávat a problém s bilancí vody v době sucha byl evidentní.

Na druhou stranu poděbradské a nymburské rybníky dokázaly prestát i katastrofální sucha 1536, 1540, 1590 a 1616. Je však jistě obtízné vzdorovat zároveň nepř́zni počasí a dobovým názorovým trendům a myšlenkovým proudům. Ty se v době osvícenství otočily prostě k rybníkům zády.

Jak uplatnit tezi o „hladu po půdě“ na rybník Blato, který zůstal téměř sto let mokrou loukou? Vyplatilo se oněch 5000 zlatých za roční pronájem hřebčína? Pokud na okamžik vynecháme ekonomickou stránku věci, pak by byl přírodní fenomén „poděbradských blat” možná ještě hodnotnější než pưvodní rybníky. Je k tomu velké množství dokladů v dobové literatuře, např. Vlastenko hospodářské společnosti. Botanickou hodnotu někdejších luk potvrzuji i dnešní odborníci vysoko [51].

Je potřeba také připomenout, jak vypadá dnešní úprava Mrliny, které je za povodně zcela odepřeno obrovské inundační území, které se rozprostírá všude kolem. Obavy před protržením hrází jsme zažili mezi lety 2003 a 2013 čtyřikrát. K jejich skutečnému protržení v minulosti došlo, jak jsme ukázali, např. za povodní v roce 1890 anebo 1926. To jsou aspekty zajímavého povodí, jehož vývoj jistě stále trvá. Poznamenejme ještě, že zatímco některé kanály jako Sánský se dochovaly jako funkční, byť v částečně pozměněné trase, Nový kanál prakticky zmizel, jeho nepatrná část je čitelná ještě v návrší Vršál u Senice. Někdejší rybníky tu víceméně zůstaly, nejmarkantněji je to vidět při cestě mezi nimi ze Senic, dále pres obec Ostrov do obce Kouty či zpět napříč Blatem po jeho dně až do Pátku. Tento cyklistický výlet lze každému vodohospodáŕi jen doporučit.

\section{SHRNUTÍ A ZÁVĚR}

Při úvahách o př́činách rušení rybníků nemůžeme extrémy počasí přecenit ani podcenit. $\vee$ řadě případů byla rozhodujícím důvodem zániku rybníka povodeň, někdy bylo „posledním hřebíčkem do rakve“ sucho. Rybníky nejsou $\checkmark$ době sucha „automatem na vodu“, ale spíše adaptačním opatřením, opěrným bodem v krajině, a to jak pro všechno živé, tak i pro člověka. Ranní mlhy jsou prínosem přinejmenším pro travní porosty, odpolední stín a ochlazení vzduchu při břehu i ve vodě úlevou pro člověka. To je ekonomie všedního dne ale i ekonomie dlouhodobého pohledu na věc.

Také dnes není lehké rozhodnout, jak se v době katastrofálního sucha chovat a jaké místo zde mají rybníky. Unáhlených řešení a obratů o $180^{\circ}$ jsme v minulých staletích zažili několik, jak bylo ukázáno. Je docela možné, že sucho bylo jedním z podnětů rybníky někdy zakládat a jindy rušit. Tento př́spěvek snad přinesl více otázek, než odpovědí. Domníváme se, že jsou to ale otázky legitimní. Ukazují mimo jiné na další rozměr fenoménu sucha a snahu o zadržování vody v krajině.

\section{Poděkování}

Děkujeme za pomoc historičce a archivářce Muzea v Poděbradech v PhDr. Heleně Lipavské, za podporu a financování sondáži děkujeme projektu LTAUSA19141 a RVO \#679 85939.

\section{Literatura}

[1] HULE, M. Rožmberkův Krčín a Krčínův Rožemberk. Třeboň, 2004, 214 s.

[2] ROZKOŠNÝ, M., PAVELKOVÁ-CHMELOVÁ, R., DAVID, V. a TRATINOVÁ, M. Zaniklé rybníky v České republice-připadové studie potenciálního využití území. VÚV TGM, v. v. i., Praha, $158 \mathrm{~s}$

[3] VAŠKU゚, Z. Doba úpadku českého rybníkárstvi a hlavni vlny rušení rybníků. VÚMOP Praha, 1995, s. 19-24. [4] VOREL, P. Zlatá doba českého rybníkářství. Dějiny a Současnost, 2008, č. 8.

[5] BALBÍN, B. Krásy a bohatství Českézemě. Praha, $350 \mathrm{~s}$

[6] KROLMUS, V. Kronyka čili dějepis všech povodní posloupných let, suchých i mokrých, úrodných a neúrodných na obili, ovoce a vína, hladů, morůajiných pohrom v KrálovstvíCeském. Tiskem Karla Wetterla, Praha, $261 \mathrm{~s}$.

[7] JONÁŠOVÁ, S. Paměti Františka Jana Vaváka, souseda a rychtáře milčického u let 1770-1816. Kniha VI-VII (1810-1816). Praha, $484 \mathrm{~s}$.

[8] SKOPEC, J. Paměti Františka J. Vaváka, souseda a rychtáre milčického z let 1770-1816. Kniha první (rok 1770-1783), část I. (1770-1780). Praha: Nákladem Dédictví sv. Jana Nepomuckého, 1910, 148 s.

[9] SKOPEC, J. Paměti Františka J. Vaváka, souseda a rychtáře milčického z let 1770-1816. Kniha první (rok 1770-1783), část II. (1781-1783). Praha: Nákladem Dědictví sv. Jana Nepomuckého, 1910, 148 s.

[10] SKOPEC, J. Paměti Františka J. Vaváka, souseda a rychtáře milčického z let 1770-1816. Kniha druhá (rok 1784-1790), část I. (1784-1786). Praha: Nákladem Dědictví sv. Jana Nepomuckého, 1910, 114 s.

[11] SKOPEC, J. Paměti Františka J. Vaváka, souseda a rychtáre milčického z let 1770-1816. Kniha druhá (rok 1784-1790), část II. (1786-1790). Praha: Nákladem Dědictví sv. Jana Nepomuckého, 1910, 169 s.

[12] SKOPEC, J. Paměti Františka J. Vaváka, souseda a rychtáre milčického z let 1770-1816. Kniha třetí (rok 1791-1801), část I. (1791-1794). Praha: Nákladem Dědictví sv. Jana Nepomuckého, 114 s.

[13] SKOPEC, J., Paméti Františka J. Vaváka, souseda a rychtáře milčického z let 1770-1816. Kniha třetí (rok 1791-1801), část III. (1798-1800). Praha: Nákladem Dědictví sv. Jana Nepomuckého, 132 s.

[14] DURČANSKÝ, M., RATAJ, T. a VOTOUPAL, I. (ed). Josef Merkl - Dějiny královského města Nymburka. Nymburk, 2012, $279 \mathrm{~s}$.

[15] DOLEŽAL, L. Úprava vodstva na Poděbradsku iv okolía jejívýsledky. Praha, 1893, $43 \mathrm{~s}$.

[16] HELLICH, J. Hospodářství rybničné na panství poděbradském, rukopis. (Originál uložen v archivu Polabského muzea). 1910 .

[17] HELLICH, J. Př́běhy mlýnů na Poděbradsku. Věstník musea v Poděbradech. 1930.

[18] WIESENFELD, K. Andenken an der dritte Versammlung deutschen Architekten und Ingenieure in Prag, im Jahre 1844. Allgemeine Bauzeitung, 1844, p. 251-261.

[19] FRANZ, H. Pamětni spis o státním stavitelství vodním a plavbě v Království českém. Technický odbor c. k. místodržitelství v Praze, 1891, 54 s.

[20] DLOUHÝ, J. a FIALA, F. Stavitelství vodní. Zprávy spolku inženýrů a architektů XXXI, 1897, s. 108-119.

[21] VEVERKA, J. K dějinám rybníkářstvíve středním Polabí. Český lid, 1949, s. 161-166.

[22] VEVERKA, J. K dějinám rybníkářství ve středním Polabí. Český lid, Bývalé rybníky na Nymbursku, 1949 , s. 205-210

[23] VEVERKA, J. K dějinám rybníkářství ve středním Polabí. Vlastivědný zpravodaj Polabí, 1965, Č́slo 3-4, s. 41-49.

[24] VEVERKA, J. K dějinám rybníkářství ve středním Polabí. Vlastivědný zpravodaj Polabí, 1965, číslo 3-4, s. 80-86.

[25] KALICOVOVÁ, V. Historický profil rybníkářství středního Polabí. Jihočeská univerzita v Českých Budějovicích, Fakulta rybářství a ochrany vod, Ústav akvakultury, Bakalářská práce, 2015, $218 \mathrm{~s}$.

[26] KUBíK, A. Historie a současnost Sánského kanálu. Vyšší odborná škola vodního hospodářství a ekologie Vodňany. Absolventská práce. 2017.

[27] VONDRKA, A. 900 let rybníkářství na Hradecku. In: David, V. a Davidová, T. Rybníky 2016. 2016, S. 54-57.

[28] SEMOTANOVÁ, E., CÍLEK, V., CZUMALO, V., FROLÍK, J., GOJDA, M., JANATA, M., KOŠŤÁK, M. a MAZUCH, M. Česko-Ottův historický atlas. Praha, $408 \mathrm{~s}$.

[29] NEJL, L. Památky v Křrinci. Křinec, 137 s.

[30] KRATOCHVÍL, A. Několik poznámek k počátkům rybníkářství v Čechách a na Moravě. In: Z historie českých rybníkü, VúMOP Praha, 1995, s. 3-18. 
[31] BRÁZDIL, R., TRNKA, M., et al. Sucho v českých zemích: minulost, současnost, budoucnost. Praha, Centrum výzkumu globální změny, Akademie věd ČR, Brno, $400 \mathrm{~s}$.

[32] Hájek z Libočan. Kronika česká. Praha, 2013, 1446 s.

[33] BRÁZDIL, R., DOBROVOLNÝ, P., TRNKA, M., ŘEZNIČKOVÁ, L., DOLÁK, L., and KOTYZA, O. Extreme droughts and human responses to them: the Czech Lands in the pre-instrumental period. Climate of the Past. 15, 2019, p. 1-24.

[34] KOTYZA, O., CVRK, F. a PAŽOUREK, V. Historické povodně na dolním Labi a Vitavě. Okresní muzeum $\checkmark$ Děčíně, 1995, 169 s.

[35] HORSÁK, J. Rukopis: Džber poděbradský. Poskytnutý: PhDr. J. Hrabětovou, Polabské muzeum $\checkmark$ Poděbradech. 1900

[36] KLÍR, T. Osídlení mezi Nymburkem a Křincem ve středověku a raném novověku. Vlastivědny zpravodaj Polabí, 2002, s. 69-92.

[37] Pilát Rakovnický. Paměti Jana Piláta Rakovnického z Jenštejna. Ed. Dvorský, 1972, s. 161-172.

[38] BRÖNIMAN, S. Climatic changes since 1700. Bern, 2015, 360 p.

[39] PEKAR̈, J. Kniha o Kosti. Praha, 1970, 341 s.

[40] BEHRINGER, W. Kulturni dějiny klimatu. Praha-Litomyšl, 2010, 404 s.

[41] FELÍR̆, F.V. Letopis 1723-1756. Praha, 2011, 471 s.

[42] KUČA, K. Chlumecko kraj rybníků. Chlumeckélisty, XXVII, 7, 2006, s. 37-39.

[43] ŠMILAUEROVÁ, E. Poděbrady v proměnách staletí. Praha 1918, 2001, $246 \mathrm{~s}$.

[44] MAREČEK, J. Sto let meliorací na Poděbradsku. Vlastivědný zpravodaj Polabí, 1982, č. 1-2.

[45] ELLEDER, L. Katastrofální povodeň roku 1846 ve stredním Polabí. Vlastivědný zpravodaj Polabi 2005-2006, 38, s. 192-213.

[46] KOKEŠ, O. Staletý boj o vodu. Vlastivědný zpravodaj Polabí, 1971, č. 1-2, s. 18-23.

[47] TOLASZ, R. a kol. Atlas podnebi Česka. Praha, 2007.

[48] BERAN, A. a KAŠPÁREK, L. Ztráta vody výparem z volné hladiny, In: DAVID, V. a DAVIDOVÁ, T. (eds.) Rybníky 2019 - sborník príspěvků z odbornékonference, 2019, s. 80-87.

[49] POKORNÝ, P., ŠíDA, P., KUNEŠ, P., CHVOJKA, O. Mezolitické osídlení bývalého jezera Švarcenberk (jižní Čechy) v kontextu vývoje prírodního prostředí. In: BENEŠ, J. a POKORNÝ, P. (eds.). Bioarcheologie $\checkmark$ České Republice - Bioarchaeology in the Czech Republic. Jihočeská Univerzita, PřF; Archeologický ústav AV ČR, České Budějovice; Praha, 2008, s. 145-176.

[50] ELLEDER, L. Hydrologické hodnocení a parametry sucha v r. 1904. In: Odborný seminár: Sucho jak mu čelit, Sborník abstraktü. ČHMÚ Praha a VúV TGM, v. v. i., 2013, s. 5-9.

[51] HOSKOVEC, L. Poděbradské Polabí, květena okolí zaniklého rybníka Blato a blatských luk. 2017. Dostupné z: https://botany.cz/cs/rybnik-blato/

\section{Autoři}

Ing. Libor Elleder, Ph.D. ${ }^{1}$

冈libor.elleder@chmi.cz

Ing. Jolana Šírová ${ }^{2}$

凶jolana.sirova@chmi.cz

Ing. Václav David, Ph.D. ${ }^{3,4}$

冈vaclav.david@fsv.cvut.cz

Ing. Ladislav Kašpárek, CSc. ${ }^{5}$

冈ladislav.kasparek@vuv.cz

doc. RNDr. Günther Kletetschka, Ph.D. ${ }^{6,7,8}$

凶kletetschka@gli.cas.cz

Zvonimír Dragoun

'ČHMÚ Praha, Oddělení aplikované hydrologie

ČHMÚ Praha, Oddělení hydrofondu a bilancí

${ }^{3}$ Katedra hydromeliorací a krajinného inženýrství,

Fakulta stavební, České vysoké učení technické v Praze
${ }^{4}$ Katedra vodních zdrojů, Fakulta agrobiologie, potravinových a přirodních zdrojů, Česká zemědělská univerzita v Praze ${ }^{5}$ Výzkumný ústav vodohospodářský T. G. Masaryka, v. v. i. ${ }^{6}$ Geologický ústav, Akademie věd ČR

7Ústav hydrogeologie, inženýrské geologie a užité geofyziky, Prírodovědecká fakulta, Univerzita Karlova

${ }^{8}$ Geophysical Institute, University of Alaska

Příspěvek prošel lektorským řízením.

\section{GROWTH AND DECLINE OF FISH- ERY IN PODĚBRADY AND NYMBURK ESTATES FROM THE POINT OF VIEW OF HISTORICAL HYDROLOGY}

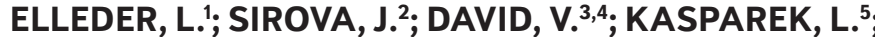 KLETETSCHKA, G.6,7,8; DRAGOUN, $Z$.}

${ }^{1} \mathrm{CHMI}$ in Prague, Department of Applied Hydrology ${ }^{2} \mathrm{CHMI}$ in Prague, Department of Hydrofond and Balances

${ }^{3}$ Department of Hydromelioration and Landscape Engineering, Faculty of Civil Engineering, Czech Technical University in Prague ${ }^{4}$ Department of Water Resources, Faculty of Agrobiology, Food and Natural Resources, Czech University of Life Sciences Prague ${ }^{5}$ TGM Water Research Institute, p.r.i.

${ }^{6}$ Institute of Geology of the Czech Academy of Sciences ${ }^{7}$ Institute of Hydrogeology, Engineering Geology and Applied Geophysics, Faculty of Science, Charles University

${ }^{8}$ Geophysical Institute, University of Alaska

Keywords: low water marks - droughts - 1790 historical hydrology - decline of fishponds - Blato

This contribution presents a current occurrence of drought periods and declines of fishponds (including entire fishpond systems), in Poděbrady and Nymburk counties. Such relation is not straightforward, when we consider fishponds as reservoirs of water and energy. Here we present, based on numerous historical examples, usefulness of a fishpond in periods of drought. We utilized recently levelled low water marks on, so called, Hungerstone in Děčín. While our focus is on the decline of the "Blato" fishpond, established near 1790, formerly the largest fishpond in the area of today's Czech Republic, we also consider if the decline of fishponds is a consequence of drought periods. 